\title{
Journal of Neurochemistry
}

\section{Both chronic treatments by epothilone $D$ and fluoxetine increase the short-term memory and differentially alter the mood-status of STOP/MAP6 KO mice}

\begin{tabular}{|c|c|}
\hline Journal: & Journal of Neurochemistry \\
\hline Manuscript ID: & JNC-E-2012-0772.R1 \\
\hline Manuscript Type: & Original Article \\
\hline Date Submitted by the Author: & $n / a$ \\
\hline Complete List of Authors: & $\begin{array}{l}\text { Fournet, Vincent; INSERM UMRS 836, Grenoble Institut Neurosciences, } \\
\text { CEA-iRTSV-GPC, Univesité Joseph Fourier, Physiopathologie du } \\
\text { cytosquelette; INSERM UMRS 952, CNRS UMR 7224, Université Pierre et } \\
\text { Marie Curie, Physiopathologie des maladies du système nerveux central } \\
\text { de Lavilléon, Gaetan; INSERM UMRS 952, CNRS UMR 7224, Université } \\
\text { Pierre et Marie Curie, Physiopathologie des maladies du système nerveux } \\
\text { central } \\
\text { Schweitzer, Annie; INSERM UMRS 836, Grenoble Institut Neurosciences, } \\
\text { CEA-iRTSV-GPC, Univesité Joseph Fourier, Physiopathologie du } \\
\text { cytosquelette } \\
\text { Giros, Bruno; INSERM UMRS 952, CNRS UMR 7224, Université Pierre et } \\
\text { Marie Curie, Physiopathologie des maladies du système nerveux central } \\
\text { Andrieux, Annie; INSERM UMRS 836, Grenoble Institut Neurosciences, } \\
\text { CEA-iRTSV-GPC, Univesité Joseph Fourier, Physiopathologie du } \\
\text { cytosquelette } \\
\text { MARTRES, Marie-Pascale; INSERM UMRS 952, CNRS UMR 7224, Université } \\
\text { Pierre et Marie Curie, Physiopathologie des maladies du système nerveux } \\
\text { central }\end{array}$ \\
\hline Area/Section: & Molecular Basis of Disease \\
\hline Keywords: & $\begin{array}{l}\text { antidepressant, microtubule-stabilizing compound, } \\
\text { serotonin/norepinephrine transporters, anxiety/depression, corticosterone, } \\
\text { stress }\end{array}$ \\
\hline
\end{tabular}


Both chronic treatments by epothilone $D$ and fluoxetine increase the short-term memory and differentially alter the mood-status of STOP/MAP6 KO mice

Vincent Fournet, ${ }^{\text {,\# }}$ Gaetan de Lavilléon,? Annie Schweitzer, ${ }^{\text {? }}$ Bruno Giros, ${ }^{\text {? }}$ Annie Andrieux ${ }^{\#}$ and Marie-Pascale Martres?

? INSERM UMRS 952, CNRS UMR 7224, Université Pierre et Marie Curie, Paris, France

\#INSERM UMRS 836, Grenoble Institut Neurosciences, CEA-iRTSV-GPC, Université Joseph Fourier, Grenoble, France

Address correspondence to Marie-Pascale Martres, INSERM UMRS 952, CNRS UMR 7224, Université Pierre et Marie Curie, Physiopathologie des maladies du système nerveux central, 9 Quai Saint Bernard, case courrier 37, 75252 Paris cedex 5, France. E-mail: marie-pascale.martres@snv.jussieu.fr

Running title: epothilone and fluoxetine improve STOP KO memory

\section{Abbreviations used:}

5-HT, serotonin; HPA, hypothalamic-pituitary-adrenal axis; KO, knockout; LTP, long term potentiation; MAP, microtubule-associated-protein; NE, norepinephrine; NET, norepinephrine transporter; PTP, post-tetanic potentiation; SERT, serotonin transporter; STOP, Stable Tubule Only Polypeptide; WT, wild-type. 


\begin{abstract}
Recent evidence underlines the crucial role of neuronal cytoskeleton in the pathophysiology of psychiatric diseases. In this line, the deletion of STOP/MAP6 (Stable Tubule Only Polypeptide), a microtubule-stabilizing protein, triggers various neurotransmission and behavioral defects, suggesting that STOP knockout (KO) mice could be a relevant experimental model for schizoaffective symptoms. To establish the predictive validity of such a mouse line, in which the brain serotonergic tone is dramatically imbalanced, the effects of a chronic fluoxetine treatment on the mood status of STOP KO mice were characterized. Moreover, we determined the impact on mood of a chronic treatment by epothilone $D$, a taxol-like microtubule-stabilizing compound that has previously been shown to improve the synaptic plasticity deficits of STOP KO mice. We demonstrated that chronic fluoxetine was either anti-depressive and anxiolytic, or pro-depressive and anxiogenic, depending on the paradigm used to test treated-mutant mice. Furthermore, control-treated STOP KO mice exhibited paradoxical behaviors, compared to their clear-cut basal mood-status. Paradoxical fluoxetine effects and control-treated STOP KO behaviors could be due to their hyperreactivity to acute and chronic stress. Interestingly, both epothilone $D$ and fluoxetine chronic treatments improved the short-term memory of STOP KO mice. Such treatments did not affect the serotonin and norepinephrine transporter densities in cerebral areas of mice. Altogether, these data demonstrated that STOP KO mice could represent a useful model to study the relationship between cytoskeleton, mood and stress. and to test innovative mood treatments, as microtubule-stabilizing compounds.
\end{abstract}

Keywords: antidepressant, anxiety/depression, corticosterone, microtubule-stabilizing compound, serotonin/norepinephrine transporters, stress. 


\section{Introduction}

Schizophrenia and mood disorders are common, chronic and debilitating psychiatric illnesses, which have a high prevalence, regardless of countries and cultures, and have a considerable socio-economic cost (Eaton et al. 2008). For example, unipolar major depression, bipolar disorder and schizophrenia are ranked 1st, 6th and 9th, respectively, in the World Health Organization estimates for disease-related lifetime disabilities and $2 \%$ of humans are affected by schizophrenia or bipolar disorder (Lopez et al. 2006, Mathers \& Loncar 2006). Although, the aetiology of schizophrenia and mood disorders is yet poorly understood, converging evidences support the view that they can arise from a deficit in cerebral connectivity, synaptic plasticity and/or neuronal architecture (Mirnics et al. 2001, Frankle et al. 2003, Owen et al. 2005, Schloesser et al. 2008).

Microtubules and microtubule effectors are of fundamental importance to neuronal differentiation and functions. Dysfunctions of the microtubule network have been shown to lead to neurodegenerative diseases and to psychiatric disorders (Gardiner et al. 2011). Recently, it was found that microtubule deregulation and alterations were related to modifications of integrated brain functions both in animal models and in psychiatric diseases. The first evidence for such a role of cytoskeleton disorganization in psychiatric-like characteristics arises from the deletion in mice of the microtubule-stabilizing protein STOP (Stable Tubule Only Polypeptide, Andrieux et al. 2002). Indeed, STOP knockout (KO) mice exhibit abnormalities of glutamatergic, dopaminergic, acetylcholinergic/nicotinic, serotonergic and noradrenergic neurotransmissions, deficits of neuronal and synaptic plasticity, sensorimotor gating impairment, associated with profound and widespread behavioral defects (Andrieux et al. 2002, Brun et al. 2005, Fradley et al. 2005, Bouvrais-Veret et al. 2007 and 2008, Powell et al. 2007, Delotterie et al. 2010, Kajitani et al. 2010, Fournet et al. $2010,2012)$. The overall phenotype of STOP KO mice suggests that they represent a relevant experimental model for schizoaffective-like characteristics. Other studies, based on human genetics, also indicate relationship between microtubule regulatory proteins and mental functions. For example, dysbindin-1 gene mutations have been reported in both schizophrenic (Straub et al. 2002, Benson et al. 2004, Norton et al. 2006) and bipolar patients (Maier 2008, Domschke et al. 2011) and this protein interacts with and regulates microtubules (Talbot et al. 2006). Similarly, mutations in DISC1 (Disrupted-In-Schizophrenia 1) gene are associated with several psychiatric diseases (schizophrenia, bipolar disorders, depression and autism (Millar et al. 2000, Ishizuka et al. 2006, Blackwood et al. 2007, Chubb et al. 2008, Kilpinen et al. 2008) and its product is a multifunctional protein acting on microtubules and on microtubule-regulatory proteins (Morris et al. 2003, Kamiya et al. 2006, Taya et al. 2007). 
A large portion of psychiatric patients are refractory to therapeutic drugs and, during drug treatments, some symptoms are moderately improved or resistant to the current therapy. For example, antipsychotics do not improve negative symptoms and cognitive deficits (Keefe et al. 2007), in spite of a therapeutic benefit for positive schizophrenia symptoms (Seeman et al. 2006). In addition, some drugs need a delay for their therapeutic action, as in the case of antidepressants that necessitate 3-6 weeks to be active (Blier \& de Montigny 1994). Finally, most of psychiatric drugs elicit a broad range of undesirable side effects, which often lead patients to cease their treatment. Based on such evidence, there is the need to find innovative targets and develop novel therapeutic drugs. In addition, an essential prerequisite for the suitability of an experimental rodent line to model psychiatriclike symptoms is that some deficits will be improved by current therapy (pharmacological or predictive validity).

In the case of STOP KO mice, chronic treatments by both typical and atypical antipsychotics improve some defects, such as the reduced number of hippocampal synaptic vesicles, the post-tetanic potentiation and/or the long-term potentiation (PTP and LTP, respectively) deficits, the nursing behavior of STOP KO females, the locomotor hyperactivity, the fragmenteous activity and the social interaction (Andrieux et al. 2002, Brun et al. 2005, Fradley et al. 2005, Delotterie et al. 2010, Merenlender-Wagner et al. 2010). Interestingly, a chronic treatment by epothilone D, a taxol microtubule-stabilizing compound (Kolman 2004, Nettles et al. 2004), also improved some deficits of STOP KO mice. In fact, it reduces the decrease of the hippocampal synaptic number, improves PTP and LTP and alleviates their disorganized spontaneous activity and maternal care deficit (Andrieux et al. 2006).

We recently show that the deletion of the STOP protein triggers a high imbalance of serotonin (5-HT) neurotransmission, with dramatic consequences (Fournet et al. 2010, 2012). Indeed, STOP KO mice are highly depressed and very less anxious than their WT littermates and exhibit impaired short- and long-term memories and spatial learning. Therefore, we characterized the effects of chronic treatment by fluoxetine, a widely used antidepressant selective for $5-\mathrm{HT}$ reuptake, as well as of chronic treatment by epothilone D. Both chronic treatments were tested on mood-status and cognitive memory of wild-type (WT) and STOP KO mice. Moreover, due to paradoxical responses of chronic control-treated STOP KO mice in some behavioral tasks, we tested their reactivity toward an acute stress. Finally, we measured the effects of fluoxetine and epothilone $D$ chronic treatments on the density of serotonin (SERT) and norepinephrine (NET) transporters, in brain areas of mice of both genotypes. 


\section{Materials and Methods}

\section{Animals}

Homozygous WT and STOP KO mice were obtained by crossing heterozygous C57BL6 STOP with heterozygous 129 SvPas STOP to get inbred C57BL6 x 129 SvPas-F1 mice and were genotyped as previously described (Andrieux et al. 2002). All mice were kept under standard conditions, under a $12 \mathrm{~h}$ light/dark cycle (lights on at 07h30) and allowed to habituate to the animal holding room for at least one week prior to use. All experiments were conducted on WT and STOP KO males of the same litters, at 3-5 months of age, in accordance with the European Communities Council directive (86/809/EEC).

\section{Drugs and treatments}

Desipramine hydrochloride was purchased from Tocris (Bristol, UK), fluoxetine hydrochloride from Sigma-Aldrich (Saint Quentin-Fallavier, France) or Lilly France (Prozac $₫$, Suresnes, France) and epothilone D from GBF (Braunschweig, Germany). $\left[{ }^{3} \mathrm{H}\right]$ Citalopram (2.22-3.18 $\mathrm{TBq} / \mathrm{mmol}$ ) and $\left[{ }^{3} \mathrm{H}\right]$ nisoxetine (2.22-3.18 TBq/mmol) were from Perkin Elmer (Orsay, France). [ $\left.{ }^{125} \mathrm{I}\right]$-RIA kit for corticosterone dosages was purchased from MP Biomedicals (Orangeburg, USA).

Epothilone D was diluted in warm water from a $16.67 \mathrm{mg} / \mathrm{ml}$ stock solution in dimethyl sulfoxide. Fluoxetine (Prozac $®, 280 \mathrm{mg} / 70 \mathrm{ml}$ ) was diluted in tap water. Male mice were housed five per cage, two cages (10 mice) per treatment and per genotype. Six groups of male mice were constituted: control-treated WT and STOP KO mice received, from day 0 and once a week, a peritoneal administration of $0.6 \%$ dimethyl sulfoxide $(100 \mu \mathrm{l} / 10 \mathrm{~g}$ body weight) and, from day $7,12 \mathrm{mg} / \mathrm{ml}$ saccharose plus $3.2 \mu \mathrm{l} / \mathrm{ml}$ glycerol in their tap drinking water; epothilone-treated WT and STOP KO mice received, from day 0 and once a week, a peritoneal administration of $1 \mathrm{mg} / \mathrm{kg}$ epothilone $\mathrm{D}(100 \mu \mathrm{l} / 10 \mathrm{~g}$ body weight $)$ and, from day 7 , $12 \mathrm{mg} / \mathrm{ml}$ saccharose plus $3.2 \mu \mathrm{l} / \mathrm{ml}$ glycerol in their tap drinking water; fluoxetine-treated WT and STOP KO mice received, from day 0 and once a week, a peritoneal administration of $0.6 \%$ dimethyl sulfoxide and, from day $7,0.05-0.07 \mathrm{mg} / \mathrm{ml}$ fluoxetine in their tap drinking water. To adjust the fluoxetine dosage at about $10 \mathrm{mg} / \mathrm{kg} / \mathrm{day} / \mathrm{mouse}$, the liquid consumption and the body weight were regularly monitored. Behavioral tests were conducted after at least 6 weeks for epothilone $D$ treatment and 5 weeks for fluoxetine treatment (supplementary data, Fig. S1A). Chronic epothilone D and fluoxetine treatments were pursued during all the behavioral studies, but were washed out one week before sacrifices.

To study the sensitivity of mice towards acute stress, animals received physiological serum (100 $\mu \mathrm{l} / 10 \mathrm{~g}$ body weight, i.p.) or not (basal) and were tested $30 \mathrm{~min}$ later in some tasks. 


\section{Behavioral tests}

All experiments were conducted between $10 \mathrm{~h} 00$ and $16 \mathrm{~h} 00$, in a sound attenuated test room where mice were allowed to habituate at least 30 min before the task.

\section{Coat State}

The coat state of treated mice was evaluated periodically by a well-trained experimenter blind to genotypes and treatments. Assessment of the coat state took into account the whole body, i.e. fur clogging, cleanness, density and scars, according to Farley et al. (2012). A score was attributed to each mouse on a scale from 0 (dirty coat) to 20 (bright and clean coat).

\section{Splash Test}

The splash test, adapted from Yalcin et al. (2008), consisted of squirting a $10 \%$ sucrose solution on the dorsal coat of a mouse in its home cage, under 15 lux illumination. After applying sucrose solution, the latency before the first grooming episode and time spent grooming were recorded for 5 minutes. The score of 1 epothilone-treated KO mouse, which did not groom, was not taken into account in analysis.

\section{Forced Swimming Test}

The forced swimming test was adapted from Porsolt et al. (1979, supplementary data). Latency before the first episode of immobility, the total duration of immobility and the number of climbing attempts were recorded for $6 \mathrm{~min}$. The scores of 1 control- and 1 epothilonetreated STOP KO mice, which did not exhibit immobility episode, were not taken into account in analysis.

\section{Tail Suspension Test}

Mice were suspended by the tail, using a paper adhesive tape, to a hook in a chamber of the apparatus (Bioseb, Vitrolles, France) under a 15 lux illumination. Their immobility time was automatically recorded during $6 \mathrm{~min}$.

\section{Marble Burying Test}

The marble burying test was adapted from Millan et al. (2001, supplementary data). The number of marbles buried by each mouse was scored every minute for 10 min and then every $5 \mathrm{~min}$ up to $20 \mathrm{~min}$.

\section{Light/Dark Box Test}

The apparatus consisted of a box $(50 \times 30 \times 30 \mathrm{~cm})$ divided by an open door providing access to a white illuminated open area (300 lux) and a dark black enclosed area (5 lux). 
Mice were placed in the center of the dark area and latency to enter in the bright area, the number of visits (with four paws) and the total time spent in the bright area were measured for 9 minutes.

\section{Spontaneous Alternation}

This test was performed under 5 lux illumination in a Y-maze (supplementary data). The number and the sequence of visits into the 3 arms were recorded during $5 \mathrm{~min}$. The score of 1 fluoxetine-treated WT mouse, which stayed immobile during the 5 min-test, was not taken into account in analysis.

\section{Novel Object Recognition Task}

This test was conducted in an arena under a 50 lux illumination (supplementary data). After habituation to arena and to objects, each mouse was placed in the center of the arena for 8 $\min$ in the presence of four identical new objects (sample phase). Mice were then removed and, after $10 \mathrm{~min}$, returned to the arena during $8 \mathrm{~min}$ for the choice phase, with two objects from the sample phase (familiar objects) and two novel identical objects. The times spent to explore novel and familiar objects were recorded. Scores of one control-treated WT, one fluoxetine-treated WT and one fluoxetine-treated STOP KO mouse, which did not explore objects, were not taken into account in analysis.

\section{Autoradiographic labelings of 5-HT and NE transporters}

Labelings of SERT and NET were performed, as detailed in supplementary data, after a 7days washout of chronic treatments to avoid occupancy of the monoamine transporters by fluoxetine, 5-HT and/or NE.

\section{Plasma corticosterone measurements}

Naïve mice received or not an intraperitoneal administration of physiological serum (100 $\mu \mathrm{l} / 10 \mathrm{~g}$ body weight) and were killed by cervical dislocation $30 \mathrm{~min}$ later. Their plasma was immediately harvested and plasma corticosterone level was determined by radioimmunoassay according to the kit manufacturer's instructions.

\section{Statistical analyses}

Data were subjected to factorial one-, two-, three- or four-way ANOVA, with genotype, treatment, area or object as between-group factors and time as within-group factor. Significant main effects were further analyzed by post hoc comparisons of means using Fisher's or Student's $t$ test. The parameters of linear regressions were calculated using GraphPad prism 5.0 software. For all tests, statistical significance was set at $p<0.05$. 


\section{Results}

The dose of the duration of chronic treatments by epothilone $D$ and fluoxetine were selected according to previous studies (Fournet et al. 2012, supplementary data). We have chosen to characterize the effects of chronic epothilone $D$ and fluoxetine treatments on three depression and two anxiety tests, as well as on two memory performance tasks, based on the clear-cut basal phenotype of STOP KO mice (Fournet et al. 2012). Moreover, all mice underwent the same series of tests to avoid different stress and environmental effects (supplementary data, Fig. S1A).

\section{Fluoxetine intake during chronic treatments (Fig. S2)}

All along the chronic treatments by epothilone $D$ or fluoxetine, the body weight and the fluid consumption of mice were monitored (Figs. S1B and S2, supplementary data). During the test period (41-63 days), the intake of fluoxetine was similar between WT and STOP KO mice $(10.6 \pm 0.6$ and $10.8 \pm 0.6 \mathrm{mg} / \mathrm{kg} /$ day, respective mean dose, Fig. S2B).

\section{Effect of chronic treatments on the depression-status}

Coat state (Fig. 1A)

The coat state of treated-WT and -STOP KO males was regularly assessed during the chronic treatments by the same experimenter. Statistical analyses showed significant effects of genotype, treatment and time (Table S1).

As already reported (Fournet et al. 2012), the coat state of male STOP KO mice was worse than that of WT mice, whatever the treatment (control: $-29 \%, p=0.0002$; epothilone D: $-21 \%, p=0.0056$; fluoxetine: $-39 \%, p<0.0001$, repeated measures). The coat state of control-treated WT mice was aggravated between days 7 and $58(-46 \%, p=0.0018)$, whereas that of control-treated STOP KO mice remained constant. Accordingly, at day 58, the coat state of control-treated WT and STOP KO mice was no longer different.

Epothilone D treatment had no effect on the coat state of both WT and mutant mice. In contrast, chronic fluoxetine significantly improved the coat state of males of both genotypes (WT: $+48 \%, p<0.0001$; STOP KO: $+28 \%, p=0.0091$; repeated measures; WT: $+137 \%, p<0.0001$, KO: $+47 \%$, ns; between days 7 and 58$)$. These latter data indicated that chronic fluoxetine was more efficacious to improve the coat state of treated-WT than -STOP KO mice.

\section{Splash test (Fig. 1B)}

Statistical analysis indicated significant effects of genotype and a near significant effect of treatment on latency to groom and of genotype and treatment on the grooming duration (Table S1). 
As already reported (Fournet et al. 2012), control treated-STOP KO mice displayed an increased careless behavior compared to control-treated mice, characterized by an increased latency to groom $(+144 \%, p=0.0003)$ and a decreased grooming $(-42 \%, p=$ 0.0038).

Epothilone D treatments had no effect on the grooming of WT and STOP KO mice. However, fluoxetine treatment exerted an antidepressant-like effect on treated-STOP KO mice by decreasing the latency $(-37 \%, p=0.0179)$ and increasing the grooming $(+54 \%, p=$ 0.0038 ), while it had no effect on WT performances. Finally, the grooming performances of fluoxetine-treated STOP KO mice did no longer differ from that of control-treated WT mice.

The significant improvement by fluoxetine treatment of the grooming behavior (state coat and splash test) of STOP KO mice was in agreement with previous study on unpredictable chronic mild stressed mice (Mutlu et al. 2009).

\section{Forced swimming test (Fig. 1C)}

This test was preferred to the tail suspension test since the determination of climbing attempts also provides information about the norepinephrine tonus of treated-mice. Statistical analyses showed significant effects of genotype and treatment on the latency, of genotype, treatment and time on the immobility, and of genotype and time on the climbing (Table S1).

In contrast with previous study performed in basal conditions (Fournet et al. 2012), the performances of control-treated STOP KO indicated a lesser despair behavior compared to WT mice, exhibiting a decreased immobility $(-62 \%, p<0.0001$, repeated measures) and increased climbing attempts $(+135 \%, p=0.0085$, repeated measures). On the other hand and as already reported (Fournet et al. 2012), latency before the first immobility episode of STOP KO mice was lesser than WT mice $(-71 \%, p=0.0014)$.

Chronic epothilone $D$ and fluoxetine treatments induced helplessness in mice of both genotypes, by decreasing latency of treated-WT mice (epothilone: $-73 \%, p=0.0007$; fluoxetine: $-78 \%, p=0.0003$ ) and increasing immobility (epothilone-WT: $+67 \%, p<0.0001$; epothilone-KO: $+123 \%, p=0.0030$; fluoxetine-WT: $+34 \%, p=0.0227$; fluoxetine-KO: $+400 \%$, $p<0.0001$ ). Epothilone $D$ and fluoxetine had no effect on the number of climbing attempts of mice of both genotypes.

\section{Summary}

As in basal conditions (Fournet et al. 2012), control-treated STOP KO mice were more depressed than control-treated WT mice in the coat state assessment (up to day 58) and in the splash test. In contrast, control-treated mutant mice exhibited a less helplessness in the forced swimming test, in disagreement with previously reported basal behaviors (Fournet et al. 2012). Whereas epothilone $D$ had no effect on the depression-status of WT and mutant mice measured by the coat state and by the splash test, it worsened performance of mice of 
both genotypes in the forced swimming test. Fluoxetine chronic treatment had an antidepressant effect on WT and STOP KO mice in the coat state and on STOP KO mice in the splash test. In contrast, it exhibited a paradoxically pro-depressant effect on WT and STOP KO mice in the forced swimming test.

\section{Effect of chronic treatments on the anxiety-status}

Marble burying test (Fig. 2A)

Genotype, treatment and time significantly affected the number of buried marbles (Table S1).

As already reported (Fournet et al. 2012), treated-STOP KO mice did not consider marbles as anxiogenic objects, since they buried less marbles than treated-WT mice (control: $-33 \%, p=0.0006$; epothilone: $-38 \%, p<0.0001$, fluoxetine: $-100 \%$, ns; repeated measures). Moreover, whereas epothilone $D$ treatment had no effect on the anxiety-status of mice, fluoxetine treatment induced a significant anxiolytic effect on mice of both genotypes by decreasing the number of buried marbles (WT: $-85 \%, p<0.0001$; STOP KO: $-100 \%, p<$ 0.0001 , repeated measures).

\section{Light/dark box test (Fig. 2B)}

Statistical analyses indicated significant effects of treatment on the latency before the first visit in the light box, of treatment on the time spent in the light box, of genotype and treatment on the visits in the light box (Table S1).

In contrast with previous results (Fournet et al. 2012), control-treated STOP KO mice did not exhibit a reduced anxiety in this test compared to control-treated WT. Epothilone had no effect on the performance of treated-WT mice, while it elicited a slight anxiogenic effect on treated-STOP KO mice by decreasing their time spent into the light box $(-43 \%, p=0.0201)$. Fluoxetine treatment clearly exhibited an anxiogenic effect on both genotypes, increasing latency (WT: $+216 \%, p=0.0020$; KO: $+158 \%, p=0.0629$ ), decreasing the time spent (WT: $89 \%, p=0.0012$; STOP KO: $-77 \%, p<0.0001$ ) and the visits (WT: $-79 \%, p=0.0059$; KO: $66 \%, p=0.0008)$ into the light box.

\section{Summary}

Control-treated STOP KO mice were less anxious than control-treated WT mice in the marble burying test, as already reported (Fournet et al. 2012). But, in disagreement with their previously reported basal performances, the anxiety-like status of control-treated STOP KO mice was not different from that of control-treated WT mice in the light/dark box test. Whereas epothilone D had little or no effect on the anxious-status of WT and mutant mice, fluoxetine elicited on both mouse lines an anxiolytic effect in the marble burying test, but an anxiogenic effect in the light/dark box test. 


\section{Chronic treatments improved the short-term memory of STOP KO mice}

\section{Spontaneous alternation (Fig. 3A)}

Statistical analyses indicated a significant effect of genotype (but not of treatment) on the total visits in the three arms of the $Y$ maze and no effect of genotype and treatment on the \% spontaneous alternation (Table S1).

As in basal conditions (Fournet et al. 2012), the total number of visits in the 3 arms of treated-STOP KO compared to treated-WT mice was significantly increased (control: $+45 \%$, $p=0.0252$; epothilone: $+71 \%, p=0.0007$; fluoxetine: $+126 \%, p=0.0001$ ), but the spontaneous alternation was not different between genotypes. Moreover, chronic epothilone and fluoxetine treatments had not effect on the two parameters.

\section{Novel object recognition (Fig. 3B)}

Statistical analyses showed significant effects of genotype and treatment on the total object recognition time (novel + familiar) during both the sample (not shown) and the choice tests and significant effects of object, of genotype $x$ object and treatment $x$ object interactions on the \% time spent with novel and familiar objects (Table S1).

As previously reported (Fournet et al. 2012), the total exploratory time of treatedSTOP KO compared to treated-WT mice was increased (control: $+138 \%, p<0.0001$; epothilone: $+100 \%, p=0.0058$; fluoxetine: $+97 \%, p=0.0249$ ). Epothilone and fluoxetine treatments had no effect on the exploratory time of WT mice, while they decreased the exploratory time of STOP KO mice (epothilone: $-23 \%, p=0.0537$; fluoxetine: $-42 \%, p=$ $0.0011)$.

In agreement with basal performances (Fournet et al. 2012), control-treated WT mice prefered novel objects after a 10-min interval between the sample- and choice-phases $(p=$ 0.0050), whereas control-treated STOP KO mice did not. Interestingly, both epothilone D and fluoxetine treatments improved the performances of STOP KO mice to distinguish the novel objects (\%Novel different from \%Familiar, epothilone: $p=0.0004$; fluoxetine: $p=0.0004$ ).

\section{Summary}

Whereas the control-treated STOP KO mice performed as well as control treated-WT mice in the spontaneous alternation test, they failed to distinguish between familiar and novel objects after a 10-min interval, as already reported (Fournet et al. 2012). Epothilone D and fluoxetine treatments had no effect on the spontaneous alternation of mice of both genotypes, however they improved the short-term memory of STOP KO mice and decreased their exploratory activity. 


\section{STOP KO mice were hyper-reactive to acute stress (Figs. 4 and 5)}

The paradoxical behaviors of control-treated STOP KO mice in the forced swimming and light/dark box tests, compared to their performances previously reported in basal conditions (Fournet et al. 2012), prompted us to analyze the effects of acute stress. Naïve male mice received or not an intraperitoneal administration of physiological serum and their depressionand anxious-performances were characterized 30 min later.

\section{Forced swimming test (Fig. 4A)}

Statistical analyses showed significant effects of genotype and stress on latency, of genotype, stress and time on the immobility time and on the climbing attempts (Table S2).

According to previous study (Fournet et al. 2012), non-injected STOP KO mice displayed a despair-like behavior compared to WT mice, characterized by decreased latency $(-56 \%, p<0.0001)$, more immobility $(+29 \%, p=0.0042$, repeated measures) and less climbing attempts $(-77 \%, p<0.0001$, repeated measures).

Whereas the saline injection had no effect on the overall behavior of WT mice, it affected significantly the behavior of STOP KO mice, which became less depressed. Indeed, saline administration decreased immobility (-46\%, $p<0.0001$, repeated measures), increased climbing attempts $(+362 \%, p<0.0001$, repeated measures $)$, but was without effect on latency.

Tail suspension test (Fig. 4B)

Genotype and stress had significant effects on the immobility time (Table S2). As already reported (Fournet et al. 2012), non-injected STOP KO mice displayed a depression-like behavior, being more immobile than WT mice $(+59 \%, p=0.0024)$. Whereas the acute stress had no effect on the immobility of WT mice, it reversed the depression-status of STOP KO mice, by decreasing the immobility of mutant males $(-60 \%, p<0.0001)$, so that it became significantly shorter than the one of saline-treated WT mice $(-40 \%, p=0.0295)$.

\section{Light/dark box test (Fig. 4C)}

Statistical analyses indicated significant effects of the genotype $\mathrm{x}$ stress interaction on latency, of genotype and stress on the time spent and the visits in the light box (Table S2).

According to previous study (Fournet et al. 2012), non-injected STOP KO mice displayed a less anxious-like behavior than WT mice, with decreased latency before the first entry in the light box $(-59 \%, p=0.0067)$, increased time spent $(+99 \%, p<0.0001)$ and visits $(+142 \%, p<0.0001)$ into the light box. The acute stress had no effect on the behavior of WT mice, while it had an anxiogenic effect on STOP KO mice, by increasing latency $(+117 \%, p=$ 0.0314 ) and decreasing both time and visits (time: $-52 \%, p<0.0001$; visits: $-50 \%, p<$ 
0.0001). Finally, the performances of saline-treated mutant mice were no longer different from that of WT mice.

\section{Plasma corticosterone levels (Fig. 5)}

Accordingly, we measured the plasma corticosterone in basal conditions or $30 \mathrm{~min}$ after saline administration to naïve WT and STOP KO males. Genotype and stress had significant effects on the corticosterone level (Table S2).

In basal conditions, the plasma corticosterone level of STOP KO mice was higher $(+83 \%, p=0.0003)$, than that of WT mice. Saline administration induced, 30 min later, a significant increase of plasma corticosterone levels in mice of both genotypes (WT: $+159 \%, p$ $<0.0001$; KO: $+59 \%, \mathrm{p}<0.0001)$ and the corticosterone level was no longer different between saline-treated WT and mutant mice. Accordingly, the \% stress-induced corticosterone increase was significantly lower in saline-treated STOP KO than in WT mice $(p<0.0001)$.

\section{Summary}

The acute stress of STOP KO mice elicited an antidepressant-like effect in the forced swimming and the tail suspension test and an anxiogenic-like effect in the light/dark box test, whereas it had no effect on WT mouse performances. These results showed that acutely stressed-STOP KO mice behaved in the same manner than chronic control-treated mutants in these tests. Moreover, based on their plasma corticosterone level, STOP KO mice were more stressed than WT mice in basal conditions, but were hyporeactive to saline administration stress.

\section{Chronic treatments had no effect on SERT and NET densities (Fig. 5B, Tables S3-S4)}

To tentatively explain the effects of chronic treatments, we measured the density of SERT and NET in various brain areas of treated-WT and -STOP KO mice. Genotype and area (but not treatment) had significant effects on the SERT and NET densities (Table S1).

As already reported (Fournet et al. 2012), parallel marked variations of SERT (Table S3) and NET (Table S4) densities were noted in control-treated STOP KO mice, with increases in the monoaminergic somas and decreases in all the projections areas. Interestingly, epothilone $D$ and fluoxetine chronic treatments had no effect in the density of SERT and NET in all tested areas in mice of both genotypes, suggesting that the behavioral effects of chronic epothilone $D$ and fluoxetine treatments are not mediated by changes in SERT and NET densities.

The variations of SERT and NET densities in STOP KO mice, expressed as \% of respective WT values, were highly correlated in basal conditions (Fournet et al. 2012) and after control-treatment (Fig. 5B; SERT: $F(1,20)=669.0, p<0.0001$; NET: $F(1,24)=268.0, p$ 
$<0.0001)$. But, whereas the slope of the linear regression for NET was not different from 1 , the slope for SERT correlation was significantly higher than $1(1.170 \pm 0.045, p<0.001)$. This result indicated that the chronic stress, induced by weekly drug administrations and numerous handlings, aggravated the disequilibrium of the $5-\mathrm{HT}$ network of STOP KO mice by $17 \%$, while it was inactive on the NE tone

\section{Compared effects of acute and chronic stress and of chronic fluoxetine on the mood of WT and STOP KO males (Tables 1-S5)}

The performances of STOP KO versus WT males in depressed-like and anxiety-like paradigms were compared in basal conditions, as already reported (Fournet et al. 2012), after acute stress due to saline administration and chronic stress due to vehicle (control)treatment (this study). The effects of chronic fluoxetine treatment were also compared on WT and STOP KO mood-status. Statistical analyses were depicted in Table S2.

Acute stress had no effect on the WT male mood. In contrast, acute stress of STOP $\mathrm{KO}$ males reversed (improved) their depression-status in the forced swimming and tail suspension tests and reversed (aggravated) their anxiety-status in the light/dark box.

Chronic stress worsened the coat state of WT males, which became equally depressed than STOP KO mice. It had no or variable (depending on the parameter) effect on the splash test and the forced swimming tests in WT males. It improved the anxiety-status of WT mice in the marble burying test, but had no effect on their performances in the light/dark box. Chronic stress elicited no effect on the coat state of STOP KO mice, an antidepressant effect on the splash test and the forced swimming test. It had no effect on the anxiety-status of STOP KO mice in the marble burying test, but reversed (aggravated) their performances in the light/dark box.

Compared to chronic stress, chronic fluoxetine treatment improved the coat state of mice of both genotypes, with a higher effect on WT than on STOP KO males. It had no effect on WT mice in the splash test, a slightly aggravating effect on their performances in the forced swimming test, an anxiolytic effect on the marble burying test, but an anxiogenic effect on the performances of WT mice in the light/dark box test. Chronic fluoxetine improved the behavior of STOP KO mice in the splash test, but aggravated their depression-status in the forced swimming test. Moreover, chronic fluoxetine treatment improved the anxiety-status of STOP KO males in the marble burying test, but aggravated their performances in the light/dark box test.

In summary, STOP KO males were hyper-reactive to acute stress and differentially sensitive to chronic stress in the different behavioral tests used. Furthermore, the two tests in which the performances of STOP KO males were inversed by acute and chronic stress, compared to basal conditions, were those in which chronic fluoxetine exerted a paradoxical 
aggravating effect both in WT and STOP KO mice, i.e. pro-depressant in the forced swimming test and anxiogenic in the light/dark box test. 


\section{Discussion}

The effects on STOP KO mice of a chronic treatment with fluoxetine, a selective SERT inhibitor, could not be foreseeable, due to the dramatic decrease of SERT density in all brain projection areas of these mice (Fournet et al. 2010, 2012). However, our present study indicated that fluoxetine treatment exerted some effects on the mood of mutant mice. Indeed, chronic treatment by fluoxetine either improved or worsened the depression- and anxietystatus of mutant mice. Control-treated STOP KO mice also exhibited paradoxical behaviors, compared to their basal status (Fournet et al. 2010). We hypothesized that the peculiar behavior of control-treated STOP KO mice, as well as the aggravating effects of chronic fluoxetine treatment, were triggered by an altered sensitivity of mutants to stress. Indeed, stress is believed to be a causal factor in the pathogenesis of psychiatric diseases, especially in mood disorders (McEwen 2003). Accordingly, we showed that acutely stressed STOP KO mice displayed a less depressed- and more anxious-status in some tests, in disagreement with their basal status. Mutant mice also exhibited enhanced plasma corticosterone level, but decreased stress-induced corticosterone stimulation. Worthy of note, our data demonstrated that both epothilone $D$ and fluoxetine chronic treatments improved the short-term memory of STOP KO mice in the novel object recognition task. Finally, neither fluoxetine, nor epothilone $D$ effects were due to variations of SERT and NET densities in the various brain areas tested.

\section{Paradoxical effects of fluoxetine on the mood-status of STOP KO mice}

We recently demonstrated that STOP KO mice exhibited high variations in SERT density, which increase in 5-HT somas and highly decrease in all the projection areas, triggering dramatic consequences on mood (Fournet et al. 2010, 2012). Actually, STOP KO mice displayed a clear-cut mood in basal conditions, i.e. a depressed- and less anxious-status. Our present data demonstrated that fluoxetine treatment triggered effects on the mood status of STOP KO mice, in spite of the highly disequilibrium of their 5-HT tone.

However, whereas chronic fluoxetine treatment clearly improved the grooming behavior of STOP KO mice, tested by the coat state and the splash test, it elicited a paradoxical response of mutant mice in the forced swimming test, another standardized paradigm for the assessment of despair behavior. Indeed, chronic fluoxetine-treatment of STOP KO mice worsened their depressed-status, by increasing their immobility time and decreasing (although not significantly) their climbing attempts and latency. The same paradoxical effect of fluoxetine was also found in the forced swimming test after an acute treatment of STOP KO mice (Fournet and Martres, unpublished observations). In the same manner, chronic fluoxetine treatment elicited an anxiolytic effect on STOP KO mice in the marble burying test, but an anxiogenic effect in the light/dark box test, by decreasing the time 
spent and number of visits in the light box of mutants. These paradoxical effects of chronic fluoxetine could unlikely be due to the fluoxetine dosage selected for chronic treatment. The relatively low dose of fluoxetine was chosen according to its acute effect on the tail suspension test (Fournet et al. 2012). At the dose of $10 \mathrm{mg} / \mathrm{kg}$, fluoxetine had no effect on the immobility of WT mice, whereas it significantly decreased the immobility of STOP KO mice. Also, the aggravating effects of fluoxetine were not due to opposite effects on WT mice, since fluoxetine parallely affected mood of WT and STOP KO mice in these tests.

Interestingly, the two tests upon which chronic fluoxetine exerted a paradoxical effect, i.e. pro-depressant in the forced swimming test and anxiogenic in the light/dark box test, were also those in which control-treated STOP KO mice responded in a paradoxical manner.

\section{Mutant mice were hyper-reactive to acute stress and not tolerant to chronic stress}

Although STOP KO mice clearly exhibited a highly depressed-status and decreased anxietystatus on a series of different tests (Fournet et al. 2012), they exhibited paradoxical responses to some despair- and anxiety-tests after chronic treatment with vehicule (controltreated). For example, they displayed a depressed-like behavior in the splash test, but they were less depressed than control-treated WT mice in the forced swimming test. In the same manner, whereas control-treated STOP KO were lesser anxious in the marble burying test than WT mice, they were equally anxious in the light/dark box test. However, such an inverted behavior of STOP KO mice was not due to changes in the mood status of controltreated WT mice. Indeed, control-treatment of WT mice had variable effects in the forced swimming and no effect in the light/dark box. Accordingly, these opposite behaviors of mutant mice prompted us to test the effects of an acute stress on their mood.

We showed that STOP KO mice were hyper-reactive to acute stress, contrasting with WT mice. In fact, an acute mild stress, induced by a peritoneal administration of saline 30 min before testing, could reverse both the depressed and the less anxious phenotype of STOP KO mice in selected tests. Acute stress exerted an antidepressant effect in mutant mice in the forced swimming and in the tail suspension tests, compared to basal (noninjected) conditions. In the same manner, acute stress had an anxiolytic effect on STOP KO mice in the light/dark box test. This hyper-reactivity of STOP KO mice to acute mild stress has already been reported on their locomotor activity (Brun et al. 2005, Fradley et al. 2005, Begou et al. 2007). In addition, our data suggested that STOP KO mice were not tolerant to chronic stress, since acute and chronic vehicule administration induced the same inverted effects on their mood (see Tables 1 and S5).

The corticosterone plasma level in basal conditions was elevated in STOP KO mice compared to WT, indicating that mutant mice were more stressed than their WT littermates. However, $30 \mathrm{~min}$ after saline administration, the increase in corticosterone level, expressed as percent of respective basal levels, was significantly lower in STOP KO than in WT mice. 
This suggests that the hypothalamic-pituitary-adrenal (HPA) axis in mutant mice may be desensitized, possibly as a consequence of a chronic state of stress. Moreover, the HPA axis being excitated by both noradrenergic and serotonergic neurotransmissions (Herman et al. 2003, Lanfumey et al. 2008), the decreased levels of 5-HT and NE found in projection areas of STOP KO (Fournet et al. 2012) could under-regulate the HPA axis.

Such a desensitization of the HPA axis in mutant mice was in disagreement with their behavioral hyper-reactivity to acute and chronic stress. An explanation of this discordance will be that the tests chosen to characterize the effect of stress, i.e. the forced swimming, tail suspension and light/dark box tests, triggered a significantly higher additional stress and that the HPA axis in mutant mice, whereas desensitized to mild stress, was hyper-reactive to higher stress. Another explanation will be that the stress induced by these behavioral tests will imply different molecular pathways from those dependent of the HPA axis.

The parallelism between the paradoxical effects of fluoxetine and the paradoxical behaviors of control-treated STOP KO mice suggested that both chronic fluoxetine treatment and chronic stress acted by the same molecular mechanism(s). Finally, since only some tests were sensitive to stress, whereas other did not, it appears to be necessary to use a battery of tests to characterize the depression- and anxiety-status of mutant mice as STOP $\mathrm{KO}$ mice, in order to avoid stress artifacts.

\section{Chronic epothilone $D$ had little if any effect on the mood of STOP KO mice}

The chronic treatment by epothilone $\mathrm{D}$, a microtubule-stabilizing taxol analog, -used in cancerology, which can cross the blood-brain barrier- only marginally affected the mood of STOP KO mice and had no effect on the mood of WT mice. It acted as a pro-depressant on the immobility time of mutant mice in the forced swimming test and as an anxiolytic compound on the time spent by STOP KO mice in the light/dark box. It had no effect on all other parameters and tests. The administered dose and the duration of the chronic treatment by epothilone $D$ were selected according to previous study (Andrieux et al. 2006) and to Andrieux and Schweitzer (personal communication). Indeed, after 8-weeks treatment of STOP KO mice, 0.3-3 mg/kg/week epothilone D has been shown to be efficacious on some deficits and ineffective on others (Andrieux et al. 2006).

Nevertheless, the absence of notable effects of chronic epothilone $D$ treatment on the mood of WT and STOP KO mice suggests that administration of this microtubule-stabilizing drug in adult mice could not have a direct impact on the 5-HT and the NE neurotransmissions and/or the HPA axis.

\section{Both epothilone D and fluoxetine improved short-term memory of STOP KO mice} Very interestingly, we showed that chronic epothilone D- and fluoxetine-treatments improved the short-term memory of STOP KO mice in the novel object recognition task. We previously 
showed that STOP KO mice exhibit preserved very short-term memory in the spontaneous alternation test, but impaired short- and long-term memories in the novel object recognition task, as well as learning and memory in the Morris watermaze test (Bouvrais-Veret et al. 2007, Fournet et al. 2012). In the present work, control-treated STOP KO mice did not distinguish between the familiar and the novel objects after a time interval of $10 \mathrm{~min}$, as in basal conditions. Very interestingly, they were able to preferentially explore novel objects after chronic epothilone $D$ - and fluoxetine-treatments.

Up to date, the only reports of a beneficial role of epothilone $D$ or $B$ on spatial learning and memory are on mouse models of tauopathy (Brunden et al. 2010, Barten et al. 2012, Zhang et al. 2012). In these studies, the cognitive improvement of the taxol-derivatives is associated with increased microtubule density, axonal integrity and decreased microtubule hyperdynamic. Such a relation between microtubule-targeting drugs and cognitive function is also found with the octapeptide NAP, a neuronal tubulin-preferring agent, in a mouse model of Alzheimer's disease (Matsuoka et al. 2008), or in heterozygous STOP mice (MerenlenderWagner et al. 2010). In our case, the improvement of short-term memory of STOP KO mice by chronic epothilone $D$ could be due to its beneficial effects on hippocampal synaptic number deficit, on post-tetanic and long-term potentiation defects and on their disorganized spontaneous activity (Andrieux et al. 2006).

Various neuropsychiatric disorders, including mood disorders, elicited impaired memory and cognitive functions (Levkovitz et al. 2002, Gallassi et al. 2006, Mostert et al. 2008). Thus, the effect of antidepressant therapy has been currently studied on a large scale of cognitive deficits, both in animal models and in human patients. Various studies reported the efficiency of chronic fluoxetine treatment on memory and learning deficits in several experimental mouse models: in two depressed models (learned helplessness and chronic mild stress, Song et al. 2006), in mice with ischemic stroke in hippocampus (Li et al. 2009) and in transgenic mice modeling the Down syndrome (Bianchi et al. 2010). Interestingly, the latter authors showed that chronic fluoxetine treatment could decrease acetylated alphatubulin, indicating increased microtubule dynamics in rat hippocampus (Bianchi et al. 2009). Finally, fluoxetine therapy has positive effects regarding the cognitive impairments of depressed patients (Austin et al. 2001, Porter et al. 2003, Weiland-Fiedler et al. 2004, Gallassi et al. 2006), Alzheimer patients (Mowla et al. 2007) or after traumatic brain injury (Horsfield et al. 2002).

\section{Chronic treatments had no effect on SERT and NET densities}

The various effects of chronic epothilone $D$ and fluoxetine treatments were not associated with consequences on the density of SERT and NET, following a 7-days washout. However, we have not measured their uptake activity. Due to the delayed onset of clinical efficacy of antidepressant therapy in mood disorders, the adaptive processes in $5-\mathrm{HT}$ 
neurotransmission to such treatments have been extensively studied. However, most works have focused on 5-HT receptor sensitivity. The consequences of prolonged antidepressant treatments on the SERT density are often controversial. For example, chronic administration of $2-10 \mathrm{mg} / \mathrm{kg} /$ day fluoxetine during 21 days induces either increase, or decrease, or has no effect on SERT brain density (Pineyro \& Blier 1999, Benmansour et al. 2002, Hirano et al. 2005). Taken together, these data indicate that adaptive responses of SERT to chronic fluoxetine treatment are not correlated with antidepressant effects.

Interestingly, we found that the \% variations of SERT and NET in both basal conditions and after control-treatment were highly correlated in various brain areas of STOP KO mice. However, the slope of the linear regression in the case of SERT was significantly higher from 1, suggesting that the chronic mild stress induced by the control-treatment exacerbated the 5-HT imbalance of STOP KO mice, whereas it was without consequence on the NE tone.

\section{Conclusion}

Stress and antidepressant actions are highly related. Accordingly, mice devoid of the STOP protein, which are pertinent for some schizoaffective-like symptoms, can constitute an original model to study such inter-relations between microtubular network, stress and mood disorders. They can be also useful to test innovative therapeutics, as those associating antipsychotic or antidepressant drugs with microtubule-stabilizing taxol analogs to alleviate some symptoms resistant to current therapy.

\section{Acknowledgements}

The Authors wish to thank Gbassay Serra for her helpful improvement of our manuscript, Johanne Germain for her expertise in the evaluation of mouse coat state, Dominique Divers for genotyping and Nicolas Damoinet for his technical assistance. This study was supported by grants from INSERM and Université Pierre et Marie Curie. Gaetan de Lavilléon is the recipient of fellowships from the MENESR (France). The authors reported no biomedical financial interest or potential conflicts of interest. 


\section{References}

Andrieux, A., Salin, P., Schweitzer, A. et al. (2006) Microtubule stabilizer ameliorates synaptic function and behavior in a mouse model for schizophrenia. Biol Psychiatry, 60, 1224-1230.

Andrieux, A., Salin, P. A., Vernet, M. et al. (2002) The suppression of brain cold-stable microtubules in mice induces synaptic defects associated with neuroleptic-sensitive behavioral disorders. Genes Dev, 16, 2350-2364.

Barten, D. M., Fanara, P., Andorfer, C. et al. (2012) Hyperdynamic microtubules, cognitive deficits, and pathology are improved in Tau transgenic mice with low doses of microtubule-stabilizing agent BMS-241027. J Neurosci, 32, 7137-7145.

Begou, M., Brun, P., Bertrand, J. B., Job, D., Schweitzer, A., D'Amato, T., Saoud, M., Andrieux, A. and Suaud-Chagny, M. F. (2007) Post-pubertal emergence of alterations in locomotor activity in stop null mice. Synapse, 61, 689-697.

Benmansour, S., Owens, W. A., Cecchi, M., Morilak, D. A. and Frazer, A. (2002) Serotonin clearance in vivo is altered to a greater extent by antidepressant-induced downregulation of the serotonin transporter than by acute blockade of this transporter. J Neurosci, 22, 6766-6772.

Benson, M. A., Sillitoe, R. V. and Blake, D. J. (2004) Schizophrenia genetics: dysbindin under the microscope. Trends Neurosci, 27, 516-519.

Bianchi, M., Shah, A. J., Fone, K. C., Atkins, A. R., Dawson, L. A., Heidbreder, C. A., Hows, M. E., Hagan, J. J. and Marsden, C. A. (2009) Fluoxetine administration modulates the cytoskeletal microtubular system in the rat hippocampus. Synapse, 63, 359-364.

Bianchi, P., Ciani, E., Guidi, S. et al. (2010) Early pharmacotherapy restores neurogenesis and cognitive performance in the Ts65Dn mouse model for Down syndrome. $J$ Neurosci, 30, 8769-8779.

Blackwood, D., Pickard, B., Thomson, P., Evans, K., Porteous, D. and Muir, W. (2007) Are some genetic risk factors common to schizophrenia, bipolar disorder and depression ? Evidence from DISC1, GRIK4 and NRG1. Neurotox Res, 11, 73-83.

Blier, P. and de Montigny, C. (1994) Current advances and trends in the treatment of depression. Trends Pharmacol Sci, 15, 220-226.

Bouvrais-Veret, C., Weiss, S., Andrieux, A., Schweitzer, A., Mclntosh, J. M., Job, D., Giros, B. and Martres, M. P. (2007) Sustained increase of alpha7 nicotinic receptors and choline-induced improvement of learning deficit in STOP knock-out mice. Neuropharmacology, 52, 1691-1700.

Bouvrais-Veret, C., Weiss, S., Hanoun, N., Andrieux, A., Schweitzer, A., Job, D., Hamon, M., Giros, B. and Martres, M. P. (2008) Microtubule-associated STOP protein deletion triggers restricted changes in dopaminergic neurotransmission. J Neurochem, 104, 745-756.

Brun, P., Begou, M., Andrieux, A. et al. (2005) Dopaminergic transmission in STOP null mice. J Neurochem, 94, 63-73.

Brunden, K. R., Zhang, B., Carroll, J. et al. (2010) Epothilone D improves microtubule density, axonal integrity, and cognition in a transgenic mouse model of tauopathy. $J$ Neurosci, 30, 13861-13866.

Chubb, J. E., Bradshaw, N. J., Soares, D. C., Porteous, D. J. and Millar, J. K. (2008) The DISC locus in psychiatric illness. Mol Psychiatry, 13, 36-64.

Delotterie, D., Ruiz, G., Brocard, J., Schweitzer, A., Roucard, C., Roche, Y., Suaud-Chagny, M. F., Bressand, K. and Andrieux, A. (2010) Chronic administration of atypical antipsychotics improves behavioral and synaptic defects of STOP null mice. Psychopharmacology (Berl), 208, 131-141.

Domschke, K., Lawford, B., Young, R. et al. (2011) Dysbindin (DTNBP1)--a role in psychotic depression? J Psychiatr Res, 45, 588-595.

Eaton, W. W., Martins, S. S., Nestadt, G., Bienvenu, O. J., Clarke, D. and Alexandre, P. (2008) The burden of mental disorders. Epidemiol Rev, 30, 1-14.

Farley, S., Dumas, S., El Mestikawy, S. and Giros, B. (2012) Increased expression of the Vesicular Glutamate Transporter-1 (VGLUT1) in the prefrontal cortex correlates with differential vulnerability to chronic stress in various mouse strains: effects of 
fluoxetine and MK-801. Neuropharmacology, 62, 503-517.

Fournet, V., Jany, M., Fabre, V. et al. (2010) The deletion of the microtubule-associated STOP protein affects the serotonergic mouse brain network. J Neurochem, 115, 1579-1594.

Fournet, V., Schweitzer, A., Chevarin, C., Deloulme, J. C., Hamon, M., Giros, B., Andrieux, A. and Martres, M. P. (2012) The deletion of STOP/MAP6 protein in mice triggers highly altered mood and impaired cognitive performances. $J$ Neurochem, 121, 99114.

Fradley, R. L., O'Meara, G. F., Newman, R. J., Andrieux, A., Job, D. and Reynolds, D. S. (2005) STOP knockout and NMDA NR1 hypomorphic mice exhibit deficits in sensorimotor gating. Behav Brain Res, 163, 257-264.

Gallassi, R., Di Sarro, R., Morreale, A. and Amore, M. (2006) Memory impairment in patients with late-onset major depression: the effect of antidepressant therapy. J Affect Disord, 91, 243-250.

Gardiner, J., Overall, R. and Marc, J. (2011) The microtubule cytoskeleton acts as a key downstream effector of neurotransmitter signaling. Synapse, 65, 249-256.

Herman, J. P., Figueiredo, H., Mueller, N. K., Ulrich-Lai, Y., Ostrander, M. M., Choi, D. C. and Cullinan, W. E. (2003) Central mechanisms of stress integration: hierarchical circuitry controlling hypothalamo-pituitary-adrenocortical responsiveness. Front Neuroendocrinol, 24, 151-180.

Hirano, K., Seki, T., Sakai, N., Kato, Y., Hashimoto, H., Uchida, S. and Yamada, S. (2005) Effects of continuous administration of paroxetine on ligand binding site and expression of serotonin transporter protein in mouse brain. Brain Res, 1053, 154-161.

Horsfield, S. A., Rosse, R. B., Tomasino, V., Schwartz, B. L., Mastropaolo, J. and Deutsch, S. I. (2002) Fluoxetine's effects on cognitive performance in patients with traumatic brain injury. Int $J$ Psychiatry Med, 32, 337-344.

Ishizuka, K., Paek, M., Kamiya, A. and Sawa, A. (2006) A review of Disrupted-InSchizophrenia-1 (DISC1): neurodevelopment, cognition, and mental conditions. Biol Psychiatry, 59, 1189-1197.

Kajitani, K., Thorne, M., Samson, M. and Robertson, G. S. (2010) Nitric Oxide Synthase Mediates the Ability of Darbepoetin Alfa to Improve the Cognitive Performance of STOP Null Mice. Neuropsychopharmacology.

Kamiya, A., Tomoda, T., Chang, J. et al. (2006) DISC1-NDEL1/NUDEL protein interaction, an essential component for neurite outgrowth, is modulated by genetic variations of DISC1. Hum Mol Genet, 15, 3313-3323.

Keefe, R. S., Bilder, R. M., Davis, S. M. et al. (2007) Neurocognitive effects of antipsychotic medications in patients with chronic schizophrenia in the CATIE Trial. Arch Gen Psychiatry, 64, 633-647.

Kilpinen, H., Ylisaukko-Oja, T., Hennah, W. et al. (2008) Association of DISC1 with autism and Asperger syndrome. Mol Psychiatry, 13, 187-196.

Kolman, A. (2004) Epothilone D (Kosan/Roche). Curr Opin Investig Drugs, 5, 657-667.

Lanfumey, L., Mongeau, R., Cohen-Salmon, C. and Hamon, M. (2008) Corticosteroidserotonin interactions in the neurobiological mechanisms of stress-related disorders. Neurosci Biobehav Rev, 32, 1174-1184.

Levkovitz, Y., Caftori, R., Avital, A. and Richter-Levin, G. (2002) The SSRIs drug Fluoxetine, but not the noradrenergic tricyclic drug Desipramine, improves memory performance during acute major depression. Brain Res Bull, 58, 345-350.

Li, W. L., Cai, H. H., Wang, B., Chen, L., Zhou, Q. G., Luo, C. X., Liu, N., Ding, X. S. and Zhu, D. Y. (2009) Chronic fluoxetine treatment improves ischemia-induced spatial cognitive deficits through increasing hippocampal neurogenesis after stroke. $J$ Neurosci Res, 87, 112-122.

Lopez, A. D., Mathers, C. D., Ezzati, M., Jamison, D. T. and Murray, C. J. (2006) Global and regional burden of disease and risk factors, 2001: systematic analysis of population health data. Lancet, 367, 1747-1757.

Maier, W. (2008) Common risk genes for affective and schizophrenic psychoses. Eur Arch Psychiatry Clin Neurosci, 258 Suppl 2, 37-40.

Mathers, C. D. and Loncar, D. (2006) Projections of global mortality and burden of disease 
from 2002 to 2030. PLoS Med, 3, e442.

Matsuoka, Y., Jouroukhin, Y., Gray, A. J. et al. (2008) A neuronal microtubule-interacting agent, NAPVSIPQ, reduces tau pathology and enhances cognitive function in a mouse model of Alzheimer's disease. J Pharmacol Exp Ther, 325, 146-153.

McEwen, B. S. (2003) Mood disorders and allostatic load. Biol Psychiatry, 54, 200-207.

Merenlender-Wagner, A., Pikman, R., Giladi, E., Andrieux, A. and Gozes, I. (2010) NAP (davunetide) enhances cognitive behavior in the STOP heterozygous mouse--a microtubule-deficient model of schizophrenia. Peptides, 31, 1368-1373.

Millan, M. J., Dekeyne, A., Papp, M., La Rochelle, C. D., MacSweeny, C., Peglion, J. L. and Brocco, M. (2001) S33005, a novel ligand at both serotonin and norepinephrine transporters: II. Behavioral profile in comparison with venlafaxine, reboxetine, citalopram, and clomipramine. J Pharmacol Exp Ther, 298, 581-591.

Millar, J. K., Wilson-Annan, J. C., Anderson, S. et al. (2000) Disruption of two novel genes by a translocation co-segregating with schizophrenia. Hum Mol Genet, 9, 1415-1423.

Morris, J., Kandpal, G., Ma, L. and Austin, C. (2003) DISC1(disrupted-in-schizophrenia 1) is a centrosome-assciated protein that interacts with MAP1A, MIPT3, ATF4/5 and NUDEL: regulation and loss if interaction with mutation. Hum Mol Genet, 12, 15911608.

Mostert, J. P., Koch, M. W., Heerings, M., Heersema, D. J. and De Keyser, J. (2008) Therapeutic potential of fluoxetine in neurological disorders. CNS Neurosci Ther, 14, 153-164.

Mowla, A., Mosavinasab, M. and Pani, A. (2007) Does fluoxetine have any effect on the cognition of patients with mild cognitive impairment? A double-blind, placebocontrolled, clinical trial. J Clin Psychopharmacol, 27, 67-70.

Mutlu, O., Ulak, G., Laugeray, A. and Belzung, C. (2009) Effects of neuronal and inducible NOS inhibitor 1-[2-(trifluoromethyl) phenyl] imidazole (TRIM) in unpredictable chronic mild stress procedure in mice. Pharmacol Biochem Behav, 92, 82-87.

Nettles, J. H., Li, H., Cornett, B., Krahn, J. M., Snyder, J. P. and Downing, K. H. (2004) The binding mode of epothilone $\mathrm{A}$ on alpha,beta-tubulin by electron crystallography. Science, 305, 866-869.

Norton, N., Williams, H. J. and Owen, M. J. (2006) An update on the genetics of schizophrenia. Curr Opin Psychiatry, 19, 158-164.

Pineyro, G. and Blier, P. (1999) Autoregulation of serotonin neurons: role in antidepressant drug action. Pharmacol Rev, 51, 533-591.

Porsolt, R. D., Bertin, A., Blavet, N., Deniel, M. and Jalfre, M. (1979) Immobility induced by forced swimming in rats: effects of agents which modify central catecholamine and serotonin activity. Eur J Pharmacol, 57, 201-210.

Powell, K. J., Hori, S. E., Leslie, R., Andrieux, A., Schellinck, H., Thorne, M. and Robertson, G. S. (2007) Cognitive impairments in the STOP null mouse model of schizophrenia. Behav Neurosci, 121, 826-835.

Seeman, P., Schwarz, J., Chen, J.-f. et al. (2006) Psychosis pathways converge via D2high dopamine receptors. Synapse, 60, 319-346.

Song, L., Che, W., Min-Wei, W., Murakami, Y. and Matsumoto, K. (2006) Impairment of the spatial learning and memory induced by learned helplessness and chronic mild stress. Pharmacol Biochem Behav, 83, 186-193.

Straub, R. E., Jiang, Y., MacLean, C. J. et al. (2002) Genetic variation in the 6p22.3 gene DTNBP1, the human ortholog of the mouse dysbindin gene, is associated with schizophrenia. Am J Hum Genet, 71, 337-348.

Talbot, K., Cho, D. S., Ong, W. Y. et al. (2006) Dysbindin-1 is a synaptic and microtubular protein that binds brain snapin. Hum Mol Genet, 15, 3041-3054.

Taya, S., Shinoda, T., Tsuboi, D. et al. (2007) DISC1 regulates the transport of the NUDEL/LIS1/14-3-3e complex through kinesin-1. J Neurosci, 27, 15-26.

Yalcin, I., Belzung, C. and Surget, A. (2008) Mouse strain differences in the unpredictable chronic mild stress: a four-antidepressant survey. Behav Brain Res, 193, 140-143.

Zhang, B., Carroll, J., Trojanowski, J. Q. et al. (2012) The microtubule-stabilizing agent, epothilone $D$, reduces axonal dysfunction, neurotoxicity, cognitive deficits, and Alzheimer-like pathology in an interventional study with aged tau transgenic mice. $J$ 
Neurosci, 32, 3601-3611.

2
3
4
5
6
7
8
9

9

10

11

12

13

14

15

16

17

18

19

20

21

22

23

24

25

26

27

28

29

30

31

32

33

34

35

36

37

38

39

40

41

42

43

44

45

46

47

48

49

50

51

52

53

54

55

56

57

58

59

60 


\section{Legends to figures}

Fig. 1. Effects of chronic epothilone $D$ and fluoxetine treatments on the depression-like status. A: Coat state. Data represent the means \pm SEM of scores of 10 WT and STOP KO males treated by vehicule $(C)$, epothilone $D(E)$ from day 1 and fluoxetine $(F)$ from day 7 . B: Splash test. Means \pm SEM of the latency time before the first grooming and of the grooming duration for 10 control-, epothilone D- and fluoxetine-treated WT and 10 control-, 9 epothilone D- and 10 fluoxetine-treated STOP KO males. C: Forced swimming test. Means \pm SEM of latency to immobilize, immobility duration and climbing attempts for 10 control-, epothilone D- and fluoxetine-treated WT and 9 control-, 9 epothilone D- and 10 fluoxetinetreated STOP KO males. Post hoc Fisher's test: ${ }^{*} p<0.050,{ }^{* *} p<0.010,{ }^{* * *} p<0.001$, comparison between genotypes; \# $p<0.050$, \# $p<0.010$, \#\# $p<0.001$, comparison between treatments; $\$ \$ p<0.001$, effect of time.

Fig. 2. Effects of chronic epothilone $D$ and fluoxetine treatments on the anxiety-like status. $A$ : Marble burying test. Means \pm SEM of the number of marbles buried by 10 control-, epothilone D- and fluoxetine-treated WT and STOP KO males. B: Light/dark box test. Means \pm SEM of latency before the first visit, the time spent and of the visit number in the light box of 10 control-, epothilone D- and fluoxetine-treated WT and STOP KO males. Post hoc Fisher's test: ${ }^{* * *} p<0.001$, comparison between genotypes; $\# p<0.050, \# \# p<0.010, \# \# p$ $<0.001$, comparison between treatments.

Fig. 3. Effects of chronic epothilone $D$ and fluoxetine treatments on the memory performances. A: Spontaneous alternation test. Means \pm SEM of the total number of visits in the three arms of the Y-maze and on the \% spontaneous alternation of 10 control-, 10 epothilone D- and 9 fluoxetine-treated WT and 10 control-, epothilone D- and fluoxetinetreated STOP KO males. B: Novel object recognition task. Means \pm SEM of the total time spent to explore the four objects in the sample-test and of the \% time to explore the novel objects in the choice-test by 9 control-, 10 epothilone D- and 9 fluoxetine-treated WT and by 10 control-, 10 epothilone D- and 9 fluoxetine-treated STOP KO males. Post hoc Fisher's test: ${ }^{*} p<0.050,{ }^{* *} p<0.010,{ }^{* * *} p<0.001$, comparison between genotypes; $\$ p=0.054$, \#\# $p<$

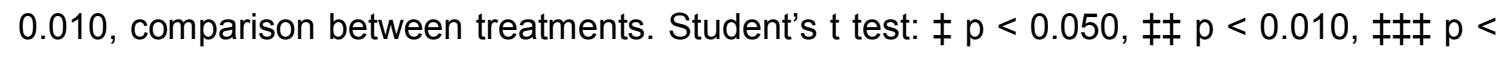
0.001 , comparison between the novel $(N)$ and familiar $(F)$ objects.

Fig. 4. Effects of acute stress on the depression- and anxiety-like status. In all tests, naïve male mice received an intraperitoneal administration of saline (Sal) or not (Bas), $30 \mathrm{~min}$ before testing. A: Forced swimming test. Means \pm SEM of latency before the first immobility episode, immobility time and climbing attempts of 11 basal and 10 saline-treated WT and of 
12 basal and 9 saline-treated STOP KO males. B: Tail suspension test. Means \pm SEM of immobility time of 12 basal and saline-treated WT and of 12 basal and 10 saline-treated STOP KO males. C: Light/Dark box test. Means \pm SEM of latency before the first visit, the time spent and the number of visits in the light box by 11 basal and saline-treated WT and 11 basal and 9 saline-treated STOP KO males. Post hoc Fisher's test: ${ }^{*} p<0.050,{ }^{* *} p<0.010$, ${ }^{* * *} p<0.001$, comparison between genotypes; \# $p<0.050$, \#\# $p<0.001$, comparison between treatments.

Fig. 5. Effect of stress on corticosterone, SERT and NET levels. A: Naïve WT and STOP KO males received an intraperitoneal administration of saline (Sal) or not (Bas), 30 min before sacrifice. Left: means \pm SEM of plasma corticosterone levels in 6 mice per genotype and treatment. Right: means \pm SEM of the stress-induced corticosterone increase, expressed as $\%$ of respective basal values. Post hoc Fisher's test: ${ }^{* * *} p<0.001$, comparison between genotypes; \#\# p < 0.001, comparison between treatments. B: Correlation of SERT and NET density in various areas of STOP KO mice, in basal condition (Fournet et al. 2012) and after chronic stress (control-treatment). 


\section{Table 1}

Compared effects of acute stress, chronic stress and chronic fluoxetine on the mood status of WT and STOP KO males

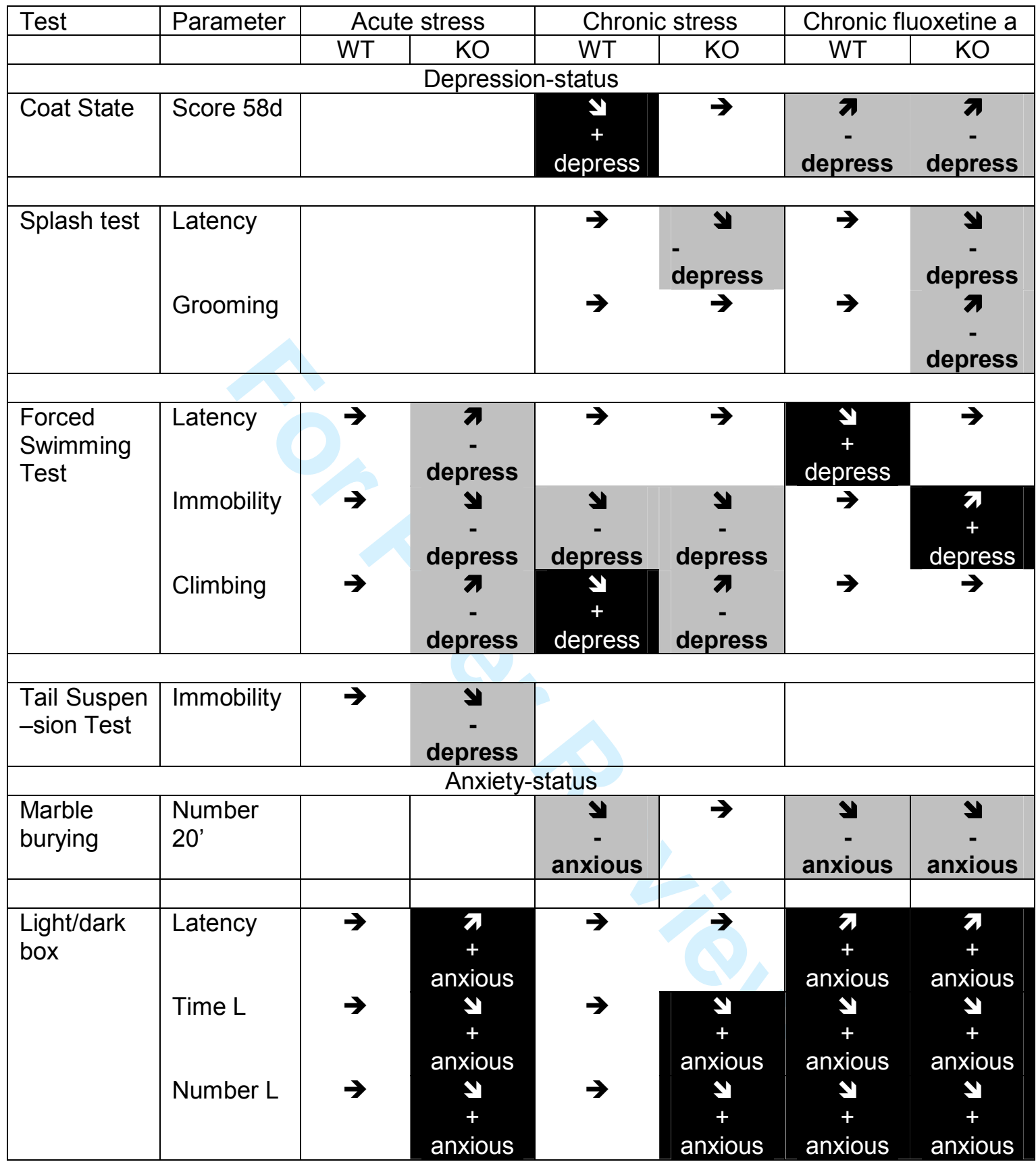

Summary of the effects of acute (acute saline administration) and chronic stress (chronic vehicle-treatment) and of chronic fluoxetine treatment on the mood-status of WT and STOP KO male, as compared with basal conditions (Fournet et al. 2012, see Table S5). $\star$, no effect; $\boldsymbol{\lambda}$, increase; $\boldsymbol{\nabla}$, decrease. Status of STOP KO versus WT mice: +, more; -, less; depress, depressed; grey bottom: improvement (antidepressant or anxiolytic), black bottom: aggravation (prodepressant or anxiogenic). a, the effects of chronic fluoxetine were compared with chronic stress; L, light box. 
The microtubule-associated STOP protein deletion triggers altered mood and cognitive performance in mice. Chronic treatments by epothilone $D$ and fluoxetine of STOP KO mice increase their short-term memory. Moreover, STOP KO mice are hypersensitive to acute and chronic stress. These mice represent a valid model to study relationship between cytoskeleton, mood disorders and stress and to test innovative therapeutics.

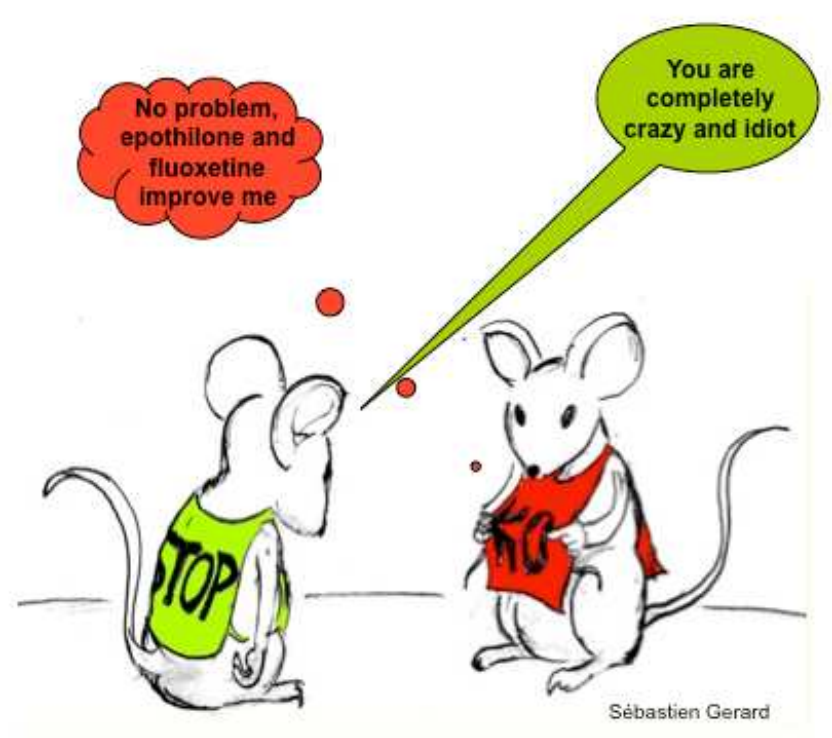

36

37 

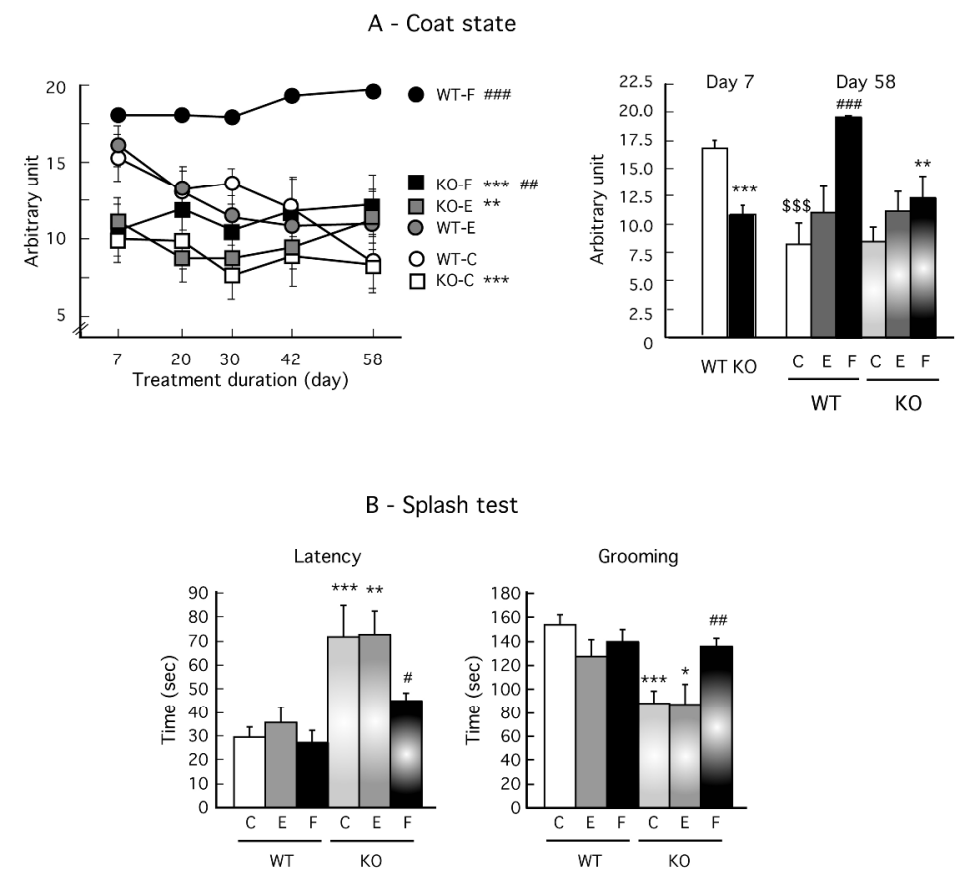

C - Forced swimming test
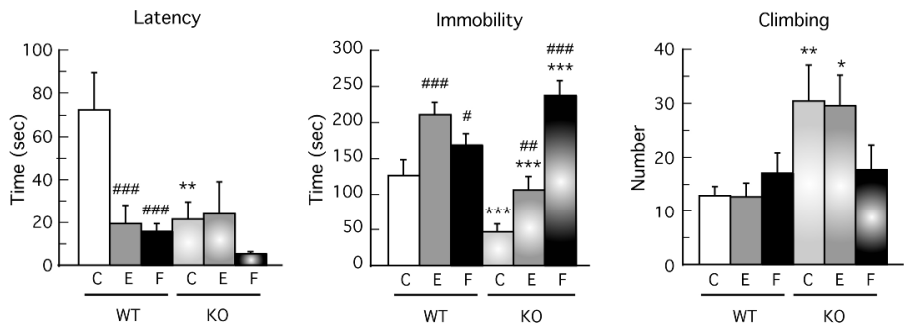

Figure 1 
A - Marble burying test

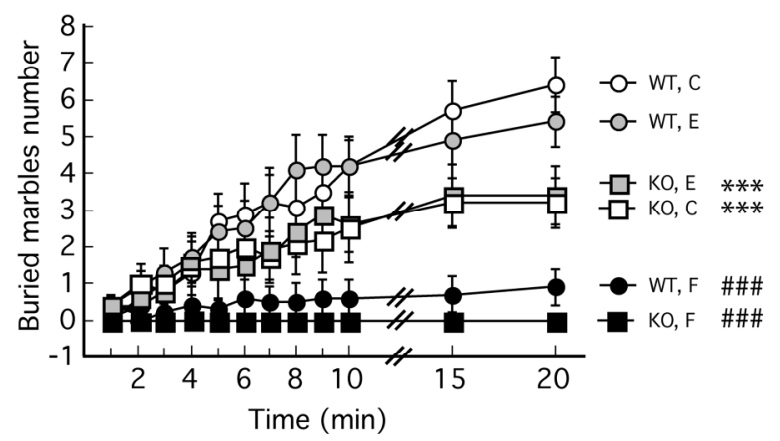

B - Light/Dark box test
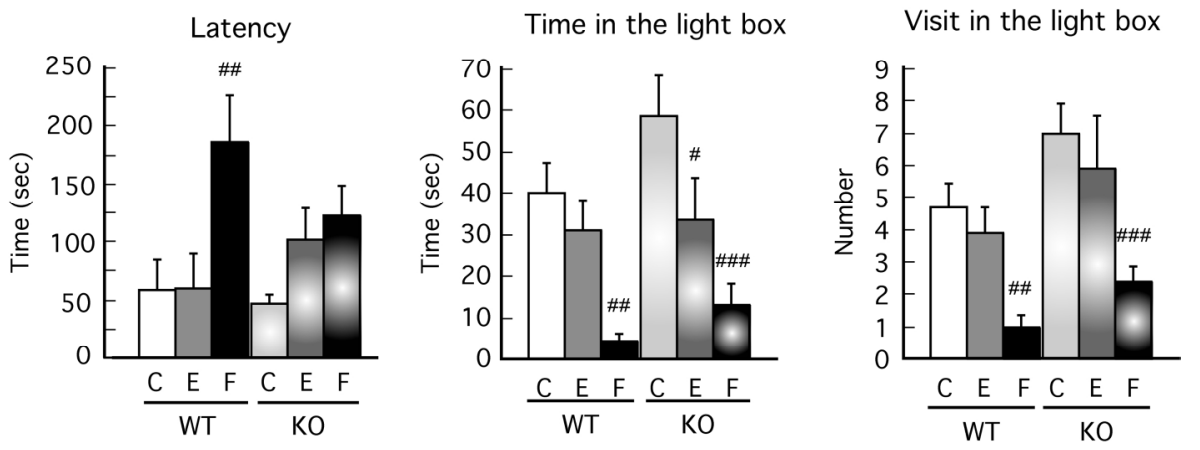

Figure 2

$188 \times 251 \mathrm{~mm}(300 \times 300 \mathrm{DPI})$ 
A - Spontaneous alternation test
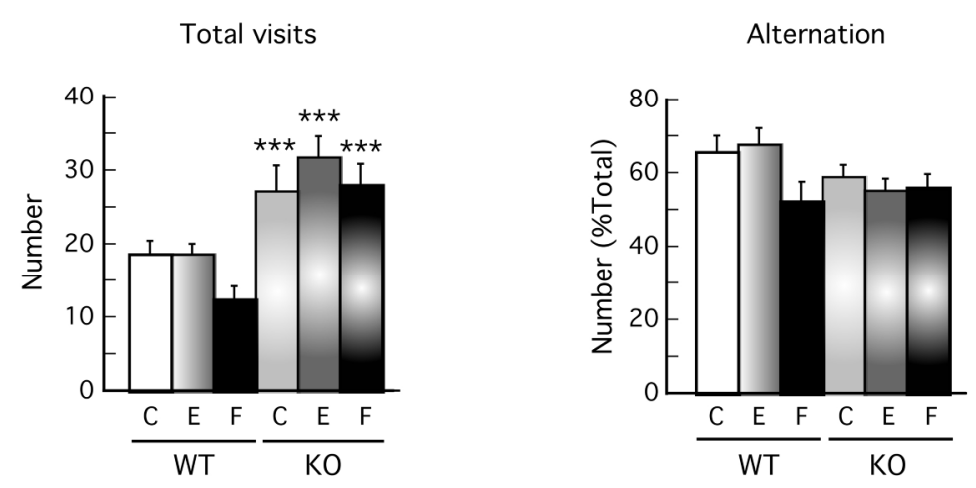

B - Object recognition task
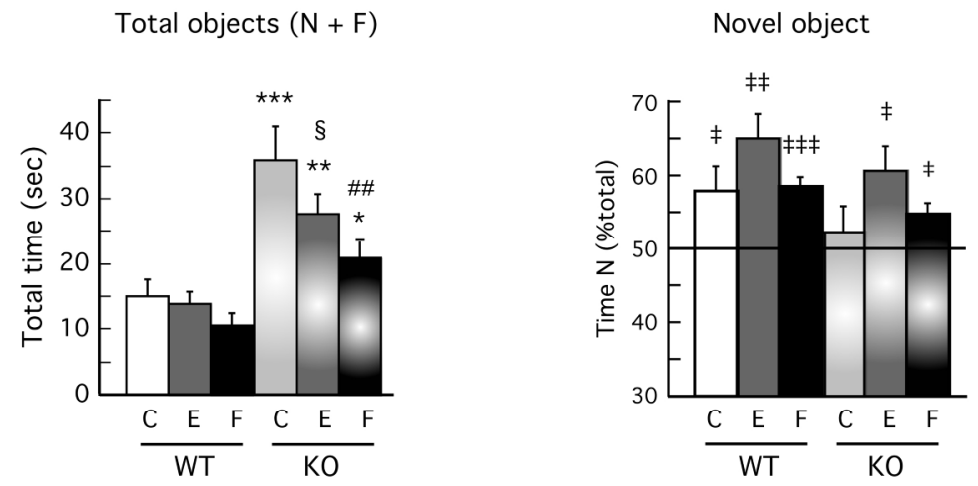

Figure 3

$191 \times 286 \mathrm{~mm}(300 \times 300$ DPI $)$ 
A - Forced swimming test
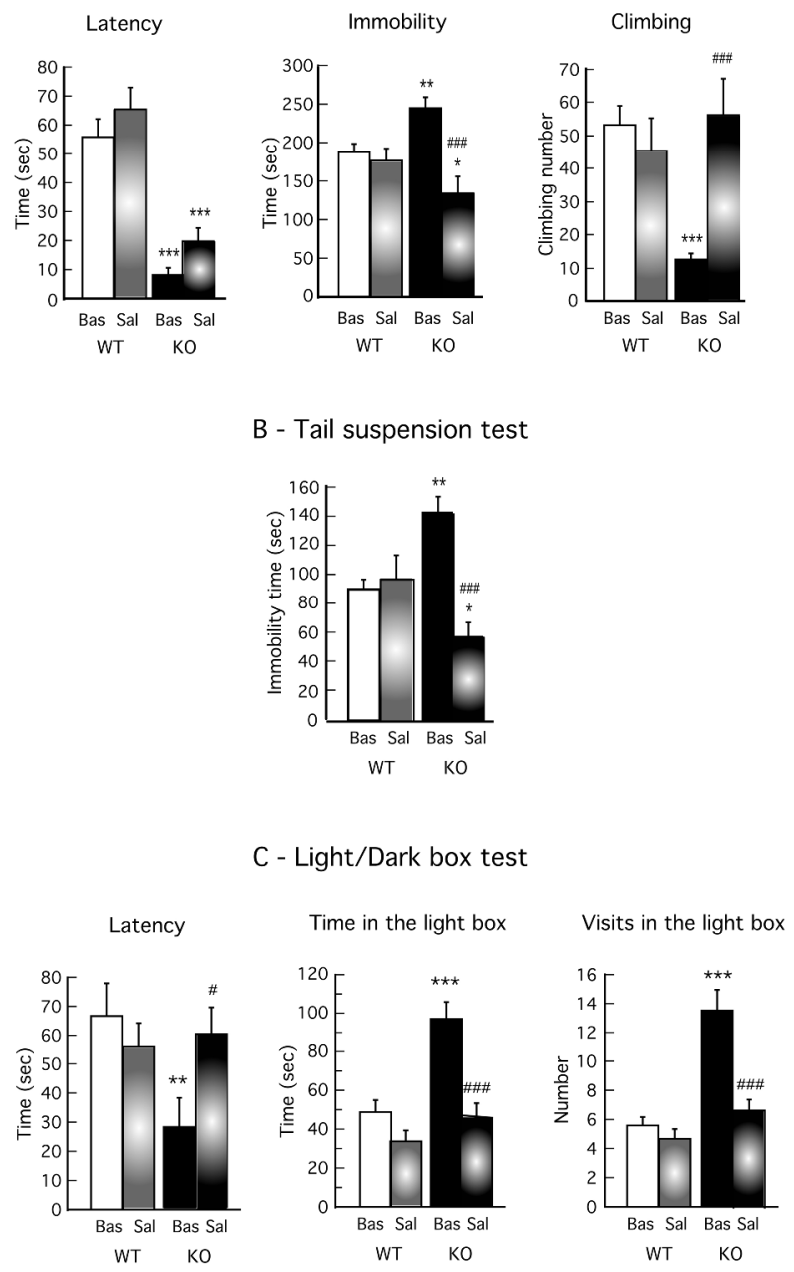

Figure 4 
A - Corticosterone level
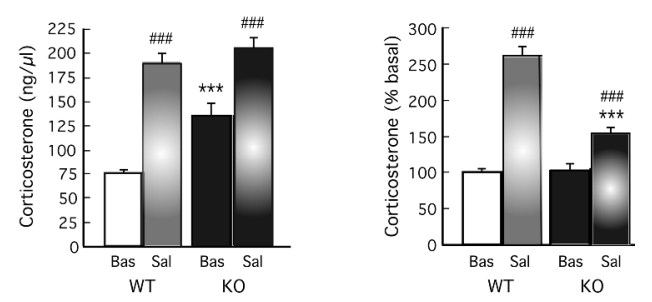

B - Correlation between basal and control-treatment
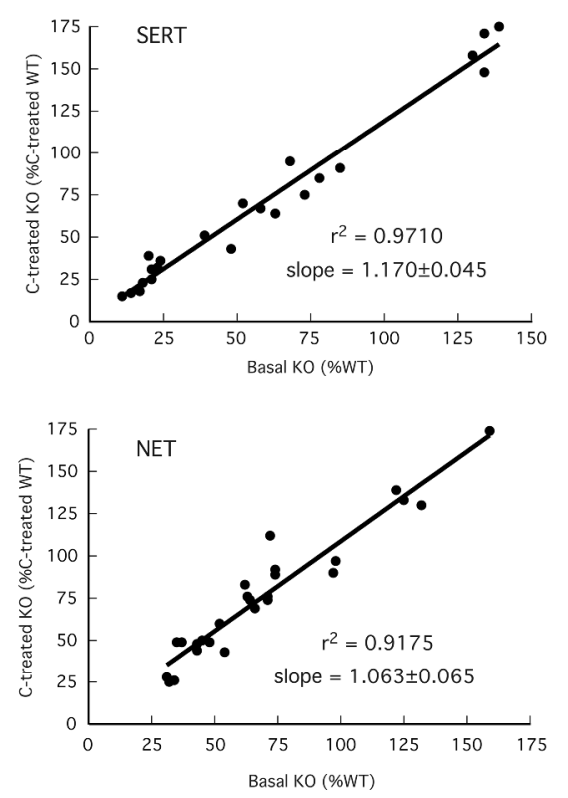

Figure 5

$262 \times 663 \mathrm{~mm}(300 \times 300$ DPI $)$ 


\section{SUPPLEMENTARY DATA}

\section{Methods}

\section{Forced Swimming Test}

The forced swimming test, adapted from Porsolt et al. (1979), was performed in a vertical glass cylinder $(h=30 \mathrm{~cm} ; d=15 \mathrm{~cm})$ containing $20 \mathrm{~cm}$ of water maintained at $24 \pm 1^{\circ} \mathrm{C}$, under 15 lux illumination. Latency before the first episode of immobility, the total duration of immobility and the number of climbing attempts were recorded for $6 \mathrm{~min}$. An animal was judged to be immobile when it remained floating passively, performing slow motion to keep its head above the water. Climbing attempts were defined by upward-directed movements of the forepaws along the side of the container.

\section{Marble Burying Test}

The procedure for the marble burying test was adapted with minor modifications from Millan et al. (2001). Mice were individually placed in transparent cages containing a $4 \mathrm{~cm}$ layer of sawdust and 12 identical glass marbles $(d=1.6 \mathrm{~cm})$ evenly spaced throughout the cage (4 rows of 3 marbles), under a 50 lux illumination. The number of marbles buried by each mouse for more than two-thirds into the sawdust was scored every minute for 10 min and then every 5 min up to 20 min.

\section{Spontaneous Alternation}

This test was conducted, as already reported (Fournet et al. 2012), under 5 lux illumination in a Y-maze consisting of 3 identical and symmetrical arms $(15 \times 5 \times 15 \mathrm{~cm})$. Each mouse was introduced at the extremity of the same arm towards the center of the maze and was allowed to explore the apparatus freely over a 5 min period. The number of entries in arms (with four paws) and the sequence of visits into the 3 arms were recorded. A spontaneous alternation was defined as entries into all 3 arms on 3 consecutive choices (e.g. 1,2,3 or 1,3,2). The \% of alternation of each mouse was expressed as the number of spontaneous alternation divided by the total number of entries minus 2 .

Novel Object Recognition Task

This test was conducted as previously reported (Fournet et al. 2012) in a 50 lux illuminated arena $(40 \times 50 \times 40 \mathrm{~cm})$, with objects that could not be displaced by the mice. Prior to the test day, mice were habituated during $8 \mathrm{~min}$ for 2 successive days to the arena without objects and then for one day in the presence of 4 identical objects located in the corners of the area $(4 \mathrm{~cm}$ from the wall). On the test day, each mouse was placed in the center of the arena for $8 \mathrm{~min}$ in the presence of four identical new objects (different from those of the habituation session) and the time spent exploring objects was recorded (sample phase). Mice were then removed and allowed to stay in their holding cage. After $10 \mathrm{~min}$, animals returned to the arena for $8 \mathrm{~min}$, with two objects from the sample phase (familiar objects) and two novel identical objects (choice phase). Between the sample and choice phases and between subjects, objects were cleaned to remove odor cues. Exploration was defined as mice directing their nose towards the object at a distance of less than $1 \mathrm{~cm}$. Sitting close to or on top of the object was not considered as exploration. The relative duration the mice explored the novel objects was calculated as the ratio of the time spent to explore the novel objects over the total time spent exploring familiar and novel objects.

\section{Autoradiographic labelings of SERT and NET}

Seven days after the end of chronic treatments, mice were killed by cervical dislocation and their brain frozen in isopentane at $-30^{\circ} \mathrm{C}$. Serial $10 \mu \mathrm{m}$ coronal sections were cut at $-20^{\circ} \mathrm{C}$, thaw-mounted on Superfrost Plus ${ }^{\circledR}$ slides and stored at $-80{ }^{\circ} \mathrm{C}$ until use. Sections were first pre-incubated before addition of radioactive ligands to rule out possible binding of 5-HT, NE, or fluoxetine to transporters.

Labeling of the 5-HT transporter (SERT) was performed according to Fournet et al. (2010, 2012), by incubating slides for $60 \mathrm{~min}$ at room temperature in $50 \mathrm{mM}$ Tris- $\mathrm{HCl}$ buffer, $\mathrm{pH} 7.4$, containing $120 \mathrm{mM} \mathrm{NaCl}, 5 \mathrm{mM} \mathrm{KCl}$ and $2.5 \mathrm{nM}\left[{ }^{3} \mathrm{H}\right]$ citalopram (2.6-3.2 TBq/mmol), with or without $10 \mu \mathrm{M}$ fluoxetine to determine non-specific binding. Sections were then washed in ice-cold buffer, rapidly rinsed in ice-cold water, dried and exposed to BAS-TR Fuji Imaging screen for 1-2 weeks. 
Labeling of the NE transporter (NET) was performed according to Ordway et al. (1997), by incubating slides for $4 \mathrm{~h}$ at $4^{\circ} \mathrm{C}$ in $50 \mathrm{mM}$ Tris- $\mathrm{HCl}$ buffer, $\mathrm{pH} 7.4$, containing 300 $\mathrm{mM} \mathrm{NaCl}, 5 \mathrm{mM} \mathrm{KCl}$ and $2.5 \mathrm{nM}\left[{ }^{3} \mathrm{H}\right]$ nisoxetine $(2.6-3.2 \mathrm{TBq} / \mathrm{mmol})$, with or without $10 \mu \mathrm{M}$ desipramine to determine non-specific binding. Sections were then washed in ice-cold buffer, rapidly rinsed in ice-cold water, dried and exposed to BAS-TR Fuji Imaging screen for 2-3 weeks.

Standard radioactive microscales were exposed onto each Imaging screen or film to ensure that labeling densities were in the linear range. The screens were scanned with a Fuji Bioimaging Analyzer BAS-5000 and the films numerized. Densitometry measurements were performed with $\mathrm{MCID}^{\mathrm{TM}}$ analysis software. Specific labelings of 4-6 sections per area were averaged per mouse. 


\section{Results and Discussion}

\section{Chronic epothilone D and fluoxetine treatments (Fig. S1A)}

The dose (1 mg/kg, once the week) and the duration (at least five weeks) of epothilone $D$ treatment were chosen according to what was previously reported (Andrieux et al. 2002, Andrieux and Schweitzer, personal communication). The dose of fluoxetine $(10 \mathrm{mg} / \mathrm{kg} / \mathrm{day})$ was chosen according to its acute inhibition of immobility of STOP KO mice in the tail suspension test (Fournet et al. 2012) and the treatment duration (at least four weeks) according to the therapeutic delay reported in the literature (Frazer \& Benmansour 2002).

\section{Effect of chronic treatments on the body weight (Fig. S1B)}

Statistical analyses of data showed significant effects of genotype, treatment and time on the body weight of treated-males (Table S1).

As already shown (Fournet et al. 2012), the body weight of STOP KO versus WT males was significantly smaller at the beginning of the treatments $(-15 \%, p<0.0001)$ and this decreased weight persisted all along the treatments (control : $-13 \%, p<0.0001$; epothilone: $-10 \%, p<0.0001$; fluoxetine: $-15 \%, p=<0.0001$; repeated measures). Whereas epothilone $D$ treatment had no effect on the weight of WT mice, it significantly increased the weight of STOP KO mice $(+5 \%, p<0.0001$, repeated measures). Fluoxetine treatment induced a significant decrease in the body weight of mice of both genotypes (WT: $-6 \%, p<$ 0.0001; STOP KO: $-9 \%, p<0.0001$, repeated measures). Finally, the body weight growth of mice during the 9-weeks treatments was not different among genotypes and treatments.

The weight loss induced by chronic fluoxetine corresponds to a well-known action of selective serotonin reuptake inhibitors, which promote hypophagia (Yen \& Fuller 1992, Curzon et al. 1997, Oruc et al. 1997) .

\section{Fluid intake during chronic treatments (Fig. S2A)}

All along the chronic treatments by epothilone $D$ or fluoxetine, the fluid consumption by treated mice of both genotypes was regularly measured. Statistical analyses showed significant effects of time and of genotype $x$ time and treatment $x$ time interactions (Table S1).

The mean fluid intake by control-treated STOP KO mice was significantly smaller compared to control-treated WT mice $(-10 \%, p=0.0417$; repeated measures). Whereas epothilone $D$ treatment significantly decreased the fluid consumption at day 9 (WT: $-19 \%, p=$ $0.0167 ; \mathrm{KO}:-37 \%, p=0.0002$ ), it had no further effect. As early as two days after the beginning of the treatment, fluoxetine elicited a decreased fluid consumption (WT: $-37 \%, p=$ 0.0002 ; KO: $-48 \%, \mathrm{p}<0.0001)$. But after a 63-day treatment, fluoxetine no longer elicited a hypodypsic effect on both WT and STOP KO mice. This tolerance of WT and STOP KO mice to the hypodypsic effect of fluoxetine could not be attributed to decreased fluoxetine intake, which was constant between days 27 and 63 (see below).

The decrease of fluid intake induced by fluoxetine is also a well known effect of 5-HT reuptake inhibitors, probably associated with their effect on food intake (Silva \& Brandao 2000, Thompson et al. 2004). Furthermore, the tolerance of mice of both genotypes to the hypodypsic effect elicited by chronic fluoxetine could be related to tolerance to the hypophagic effect of chronic fluoxetine (McGuirk et al. 1992).

\section{Effect of chronic treatments on SERT and NET density (Tables S3-S4)}

Statistical analysis showed significant effects of genotype and area on the density of SERT and NET in various brain areas (Table S2). Importantly, treatment had no significant effect on SERT and NET densities of treated-WT and -STOP KO mice.

As already reported (Fournet et al. 2010, 2012), SERT density (Table S3) in controltreated STOP KO versus WT mice was increased in the cell body areas containing noradrenergic (locus coeruleus: $+45 \%$ ), serotonergic (dorsal raphe intermediate: $+39 \%$, dorsal raphe: $+43 \%$ and median nucleus raphe: $+27 \%$ ) and dopaminergic (substantia nigra: $+35 \%$ and ventral tegmental area: $+45 \%)$ somas. In contrast, SERT density was highly decreased in all projection areas (from $-30 \%$ in medial septum to $-90 \%$ in medial entorhinal cortex).

In the same manner but at a lesser extent, NET density (Table S4), in control-treated STOP KO versus WT mice, was increased in the cell body areas containing serotonergic 
Page 37 of 50

Journal of Neurochemistry

1

1
3
4

4

5

6

7

8

9

10

11

12

13

14

15

16

17

18

19

20

21

22

23

24

25

26

27

28

29

30

31

32

33

34

35

36

37

38

39

40

41

42

43

44

45

46

47

48

49

50

51

52

53

54

55

56

57

58

59

60

(dorsal rape intermediate: $+17 \%$, dorsal rape: $+32 \%$ and median nucleus rape: $+42 \%$ ) and dopaminergic (ventral tegmental area: $+21 \%$ ) somas. In contrast, NET density was decreased in all projection areas (from $-25 \%$ in medial septum to $-70 \%$ in medial entorhinal cortex). Finally, NET density was not different in the locus coeruleus and substantia nigga of control-treated STOP KO versus WT mice, as in basal conditions (Fournet et al. 2012). Interestingly, treatments by epothilone $\mathrm{D}$ and fluoxetine did not modify SERT and NET densities in the cerebral areas of treated-WT and -STOP KO mice.

Comparison of the acute and chronic stress effects in the depression- and anxietystatus (Table S5)

The performances of WT and STOP KO males in depressed- and anxiety-like tests were compared in basal conditions, after acute stress and chronic stress and after chronic fluoxetine (data for male mice from Fournet et al. 2012 and our present study).

In the coat state, analyses of data showed significant effects of genotype and treatment; in the splash test, there were significant effects of genotype and treatment on latency and of genotype on the grooming duration; in the forced swimming test, analyses indicated a significant effect of genotype on latency, significant effects of genotype and treatment on the immobility time and the climbing attempts; in the tail suspension test, genotype and genotype $x$ treatment interaction had significant effects on the immobility time (Table S2).

Analyses of data indicated significant effects of genotype and treatment on the number of buried marbles and on latency, time spent and number of visits into the light box of the light/dark box test (Table S2).

4 


\section{References}

Andrieux, A., Salin, P. A., Vernet, M. et al. (2002) The suppression of brain cold-stable microtubules in mice induces synaptic defects associated with neuroleptic-sensitive behavioral disorders. Genes Dev, 16, 2350-2364.

Curzon, G., Gibson, E. L. and Oluyomi, A. O. (1997) Appetite suppression by commonly used drugs depends on 5-HT receptors but not on 5-HT availability. Trends Pharmacol Sci, 18, 21-25.

Fournet, V., Jany, M., Fabre, V. et al. (2010) The deletion of the microtubule-associated STOP protein affects the serotonergic mouse brain network. J Neurochem, 115, 1579-1594.

Fournet, V., Schweitzer, A., Chevarin, C., Deloulme, J. C., Hamon, M., Giros, B., Andrieux, A. and Martres, M. P. (2012) The deletion of STOP/MAP6 protein in mice triggers highly altered mood and impaired cognitive performances. J Neurochem, 121, 99114.

Franklin, K. B. and Paxinos, G. (1997) The mouse brain in stereotaxic coordinates. Academic Press, Inc., San Diego, CA, USA.

Frazer, A. and Benmansour, S. (2002) Delayed pharmacological effects of antidepressants. Mol Psychiatry, 7 Suppl 1, S23-28.

McGuirk, J., Muscat, R. and Willner, P. (1992) Effects of chronically administered fluoxetine and fenfluramine on food intake, body weight and the behavioural satiety sequence. Psychopharmacology (Berl), 106, 401-407.

Millan, M. J., Dekeyne, A., Papp, M., La Rochelle, C. D., MacSweeny, C., Peglion, J. L. and Brocco, M. (2001) S33005, a novel ligand at both serotonin and norepinephrine transporters: II. Behavioral profile in comparison with venlafaxine, reboxetine, citalopram, and clomipramine. J Pharmacol Exp Ther, 298, 581-591.

Ordway, G. A., Stockmeier, C. A., Cason, G. W. and Klimek, V. (1997) Pharmacology and distribution of norepinephrine transporters in the human locus coeruleus and raphe nuclei. J Neurosci, 17, 1710-1719.

Oruc, L., Verheyen, G., Furac, I., Jakovlejevic, M., Ivezic, S., Raeymaekers, P. and Van Broeckhoven, C. (1997) Association analysis of the 5-HT2C receptor and 5-HT transporter genes in bipolar disorder. Am J Medical Genetics (Neuropsychiatric Genetics), 74, 504-506.

Porsolt, R. D., Bertin, A., Blavet, N., Deniel, M. and Jalfre, M. (1979) Immobility induced by forced swimming in rats: effects of agents which modify central catecholamine and serotonin activity. Eur J Pharmacol, 57, 201-210.

Silva, R. C. and Brandao, M. L. (2000) Acute and chronic effects of gepirone and fluoxetine in rats tested in the elevated plus-maze: an ethological analysis. Pharmacol Biochem Behav, 65, 209-216.

Thompson, M. R., Li, K. M., Clemens, K. J., Gurtman, C. G., Hunt, G. E., Cornish, J. L. and McGregor, I. S. (2004) Chronic fluoxetine treatment partly attenuates the long-term anxiety and depressive symptoms induced by MDMA ('Ecstasy') in rats. Neuropsychopharmacology, 29, 694-704.

Yen, T. T. and Fuller, R. W. (1992) Preclinical pharmacology of fluoxetine, a serotonergic drug for weight loss. Am J Clin Nutr, 55, 177S-180S. 


\section{Legends to figures}

Fig. S1. A: Schema of chronic treatments and of the test sequence. B: Effects of chronic treatments on the body weight. Means \pm SEM of 10 males per genotype and per treatment. C, E and F: control-, epothilone $D$ and fluoxetine chronic treatments, respectively. Post hoc Fisher's test: ${ }^{*} p<0.050,{ }^{* * *} p$ $<0.001$, comparison between genotypes; \#\#\# $p<0.001$, comparison between treatments (repeated measures); $\$ \$ p<0.010, \$ \$ p<0.001$, comparison between times.

Fig. S2. A: Total fluid consumption. Left: time course of total fluid consumption of 10 males per genotype and per treatment. Means \pm SEM expressed in $\mathrm{ml} / 10 \mathrm{~g}$ body weight/day. Right: comparison of the fluid consumption between day 9 and day 63. Means \pm SEM. B: time course of fluoxetine consumption between day 9 and day 63 . Means \pm SEM in $\mathrm{mg} / \mathrm{kg} /$ day for 10 males per genotype and per treatment. Dashed straights: mean fluoxetine consumption during the test period (day 41 to day 63). Post hoc Fisher's test: ${ }^{*} p<0.050,{ }^{* *} p<0.010$, ${ }^{* * *} p<0.001$, comparison between genotypes; $\# \# p<0.010$, \#\#\# $p<0.001$, comparison between treatments; $\$ \$ p<0.001$, comparison between days of treatment. 
Table S1 Statistical analyses

\begin{tabular}{|c|c|c|c|c|c|c|}
\hline Test & Figure & Parameter & Factor & degree & $\mathrm{F}$ & $p$ \\
\hline \multirow[t]{3}{*}{ Body weight } & Fig S1B & Weight a & time & 7,42 & 12.30 & $<0.0001$ \\
\hline & & & genotype $\mathrm{x}$ time & 7,42 & 2.18 & 0.0557 \\
\hline & & & treatment $x$ time & 14,42 & 5.26 & $<0.0001$ \\
\hline \multirow[t]{4}{*}{ Fluid intake } & Fig S2A & Quantity a & genotype & 1,42 & 15.27 & 0.0079 \\
\hline & & & treatment & 2,42 & 5.41 & 0.0454 \\
\hline & & & & 7,42 & 12.40 & $<0.0001$ \\
\hline & & & treatment $x$ time & 14,42 & 4.44 & $<0.0001$ \\
\hline \multirow{4}{*}{$\begin{array}{l}\text { Fluoxetine } \\
\text { intake }\end{array}$} & Fig S2B & Dose a & genotype & 1,144 & 4.20 & 0.0554 \\
\hline & & & & 8,144 & 39.59 & $<0.0001$ \\
\hline & & & genotype $\mathrm{x}$ time & 8,144 & 6.55 & $<0.0001$ \\
\hline & & Dose 6-9 w a & time & 2,36 & 34.59 & $<0.0001$ \\
\hline \multirow[t]{5}{*}{ Coat state } & Fig $1 \mathrm{~A}$ & Score a & genotype & 1,216 & 19.79 & $<0.0001$ \\
\hline & & & treatment & 2,216 & 7.27 & 0.0016 \\
\hline & & & time & 4,126 & 3.91 & 0.0044 \\
\hline & & & genotype $\mathrm{x}$ time & 4,216 & 3.13 & 0.0156 \\
\hline & & & treatment $x$ time & 8,216 & 3.99 & 0.0002 \\
\hline \multirow[t]{5}{*}{ Splash test } & Fig 1B & Latency & genotype & 1,53 & 25.67 & $<0.0001$ \\
\hline & & & treatment & 2,53 & 2.99 & 0.0586 \\
\hline & & Grooming & genotype & 1,53 & 15.27 & 0.0003 \\
\hline & & & treatment & 2,53 & 3.68 & 0.0319 \\
\hline & & & genotype $\mathrm{x}$ treatment & 2,53 & 3.83 & 0.0279 \\
\hline \multirow{11}{*}{$\begin{array}{l}\text { Forced } \\
\text { swimming } \\
\text { test }\end{array}$} & Fig 1C & Latency & genotype & 1,52 & 4.86 & 0.032 \\
\hline & & & treatment & 2,52 & 6.24 & 0.0037 \\
\hline & & & genotype $\mathrm{x}$ treatment & 2,52 & 3.65 & 0.0329 \\
\hline & & Immobility a & genotype & 1,104 & 6.80 & 0.0119 \\
\hline & & & treatment & 2,104 & 21.85 & $<0.0001$ \\
\hline & & & genotype $x$ treatment & 2,104 & 14.04 & $<0.0001$ \\
\hline & & & time & 2,104 & 18.55 & $<0.0001$ \\
\hline & & & genotype $x$ time & 2,104 & 5.37 & 0.0061 \\
\hline & & & genotype $x$ treatment $x$ time & 4,104 & 3.37 & 0.0123 \\
\hline & & Climbing a & genotype & 1,104 & 10.68 & 0.0019 \\
\hline & & & time & 2,104 & 25.17 & $<0.0001$ \\
\hline \multirow[t]{5}{*}{ Marble burying } & Fig 2A & Number bur a & genotype & 1,594 & 4.44 & 0.0397 \\
\hline & & & treatment & 2,594 & 13.51 & $<0.0001$ \\
\hline & & & & 11,594 & 41.91 & $<0.0001$ \\
\hline & & & genotype $x$ time & 11,594 & 5.06 & $<0.0001$ \\
\hline & & & treatment $x$ time & 22,594 & 8.19 & $<0.0001$ \\
\hline \multirow[t]{4}{*}{ Light/Dark box } & Fig $2 \mathrm{~B}$ & Latency & treatment & 2,54 & 7.06 & 0.0019 \\
\hline & & Time L & treatment & 2,54 & 15.27 & $<0.0001$ \\
\hline & & Visit L & genotype & 1,54 & 6.49 & 0.0137 \\
\hline & & & treatment & 2,54 & 11.34 & $<0.0001$ \\
\hline Spontan Alter & Fig $3 \mathrm{~A}$ & Tot Entries & genotype & 1,53 & 33.98 & $<0.0001$ \\
\hline \multirow{6}{*}{$\begin{array}{l}\text { Object } \\
\text { recognition } \\
\text { task }\end{array}$} & not shown & Time: pre-test & $\begin{array}{l}\text { genotype } \\
\text { treatment }\end{array}$ & $\begin{array}{l}1,51 \\
2,51\end{array}$ & $\begin{array}{c}44.91 \\
4.53\end{array}$ & $\begin{array}{c}<0.0001 \\
0.0155\end{array}$ \\
\hline & Fig 3B & Time: test & genotype & 1,51 & 35.78 & $<0.0001$ \\
\hline & & & treatment & 2,51 & 4.92 & 0.0111 \\
\hline & & \%Time F, N & object & 1,102 & 84.69 & $<0.0001$ \\
\hline & & & genotype $\mathrm{x}$ object & 1,102 & 7.03 & 0.0093 \\
\hline & & & treatment $\mathrm{x}$ object & 2,102 & 7.75 & 0.0007 \\
\hline \multirow[t]{3}{*}{ SERT } & Table S3 & Density & genotype & 1,529 & 8.12 & 0.0046 \\
\hline & & & area & 22,529 & 480.20 & $<0.0001$ \\
\hline & & & genotype $\mathrm{x}$ area & 22,529 & 21.69 & $<0.0001$ \\
\hline \multirow[t]{3}{*}{ NET } & Table S4 & Density & genotype & 1,584 & 29.684 & $<0.0001$ \\
\hline & & & area & 22,584 & 405.88 & $<0.0001$ \\
\hline & & & genotype $\mathrm{x}$ area & 22,584 & 3.61 & $<0.0001$ \\
\hline
\end{tabular}

Only the significant ANOVA values are provided. a: repeated measures; bur: buried; $F, N$, familiar or novel object; L: light box; Spontan Alter: spontaneous alternation; Tot: total; w: week. 
Table S2 Statistical analyses

\begin{tabular}{|c|c|c|c|c|c|c|}
\hline Test & Figure & Parameter & Factor & degree & $\mathrm{F}$ & $p$ \\
\hline \multicolumn{7}{|c|}{ Acute stress versus basal } \\
\hline \multirow{10}{*}{$\begin{array}{l}\text { Forced } \\
\text { swimming test }\end{array}$} & \multirow[t]{10}{*}{ Fig 4A } & Latency & genotype & 1,39 & 77.30 & $<0.0001$ \\
\hline & & Immobility a & stress & 1,78 & 16.50 & 0.0002 \\
\hline & & & genotype $x$ stress & 1,78 & 10.74 & 0.0022 \\
\hline & & & & 2,78 & 20.78 & $<0.0001$ \\
\hline & & & genotype $x$ time & 2,78 & 13.78 & $<0.0001$ \\
\hline & & Climbing a & genotype & 1,78 & 4.36 & 0.0434 \\
\hline & & & stress & 1,78 & 5.96 & 0.0193 \\
\hline & & & genotype $x$ stress & 1,78 & 12.82 & 0.0009 \\
\hline & & & & 2,78 & 30.57 & $<0.0001$ \\
\hline & & & genotype $x$ time & 2,78 & 21.60 & $<0.0001$ \\
\hline \multirow{2}{*}{$\begin{array}{l}\text { Tail suspension } \\
\text { test }\end{array}$} & \multirow[t]{2}{*}{ Fig 4B } & Immobility & stress & 1,42 & 11.21 & 0.0017 \\
\hline & & & genotype $x$ stress & 1,42 & 14.93 & 0.0004 \\
\hline \multirow[t]{7}{*}{ Light/Dark box } & \multirow[t]{7}{*}{ Fig 4D } & Latency & genotype $x$ stress & 1,34 & 4.74 & 0.0365 \\
\hline & & Time L & genotype & 1,34 & 18.73 & 0.0001 \\
\hline & & & stress & 1,34 & 21.67 & $<0.0001$ \\
\hline & & & genotype $x$ stress & 1,34 & 6.25 & 0.0174 \\
\hline & & Visit L & genotype & 1,34 & 29.64 & $<0.0001$ \\
\hline & & & stress & 1,34 & 17.73 & 0.0002 \\
\hline & & & genotype $x$ stress & 1,34 & 10.53 & 0.0026 \\
\hline \multirow[t]{6}{*}{ Corticosterone } & \multirow[t]{6}{*}{ Fig 5} & Plasma level & genotype & 1,20 & 14.90 & 0.0010 \\
\hline & & & stress & 1,20 & 92.67 & $<0.0001$ \\
\hline & & & genotype $x$ stress & 1,20 & 5.70 & 0.0270 \\
\hline & & $\%$ Increase & genotype & 1,20 & 32.26 & $<0.0001$ \\
\hline & & & stress & 1,20 & 127.12 & $<0.0001$ \\
\hline & & & genotype $x$ stress & 1,20 & 32.26 & $<0.0001$ \\
\hline \multicolumn{7}{|c|}{ Acute \& chronic stress and fluoxetine versus basal } \\
\hline \multirow[t]{3}{*}{ Coat state } & Table S5 & Score $b$ & genotype & 1,65 & 21.01 & $<0.0001$ \\
\hline & & & treatment & 2,65 & 18.27 & $<0.0001$ \\
\hline & & & genotype $x$ treatment & 2,65 & 5.23 & 0.0007 \\
\hline \multirow[t]{6}{*}{ Splash test } & Table S5 & Latency & genotype & 1,62 & 30.74 & $<0.0001$ \\
\hline & Table S5 & & treatment & 2,62 & 9.71 & 0.0002 \\
\hline & & & genotype $x$ treatment & 2,62 & 5.44 & 0.0067 \\
\hline & & Grooming & genotype & 1,62 & 26.03 & $<0.0001$ \\
\hline & & & treatment & 2,62 & 5.06 & 0.0092 \\
\hline & & & genotype $\mathrm{x}$ treatment & 2,62 & 5.28 & 0.0076 \\
\hline \multirow{7}{*}{$\begin{array}{l}\text { Forced } \\
\text { swimming test }\end{array}$} & Table S5 & Latency & genotype & 1,74 & 50.55 & $<0.0001$ \\
\hline & & & treatment & 3,74 & 8.60 & $<0.0001$ \\
\hline & & & genotype $\mathrm{x}$ treatment & 3,74 & 2.99 & 0.0363 \\
\hline & & Immobility & treatment & 3,74 & 25.31 & $<0.0001$ \\
\hline & & & genotype $\mathrm{x}$ treatment & 3,74 & 9.80 & $<0.0001$ \\
\hline & & Climbing & treatment & 3,74 & 11.26 & $<0.0001$ \\
\hline & & & genotype $x$ treatment & 3,74 & 9.96 & $<0.0001$ \\
\hline \multirow{3}{*}{$\begin{array}{l}\text { Tail suspension } \\
\text { test } \\
\text { Marble burying }\end{array}$} & Table S5 & Immobility & treatment & 1,42 & 11.21 & 0.0017 \\
\hline & & & genotype $\mathrm{x}$ treatment & 1,42 & 14.93 & 0.0004 \\
\hline & Table S5 & Number bur $\mathrm{c}$ & genotype & 1,65 & 33.86 & $<0.0001$ \\
\hline & & & treatment & 2,65 & 34.77 & $<0.0001$ \\
\hline & & & genotype $x$ treatment & 2,65 & 10.33 & $<0.0001$ \\
\hline \multirow[t]{9}{*}{ Light/Dark box } & Table S5 & Latency & genotype & 1,68 & 4.42 & 0.0388 \\
\hline & & & treatment & 3,68 & 20.65 & $<0.0001$ \\
\hline & & & genotype $x$ treatment & 3,68 & 3.01 & 0.0361 \\
\hline & & Time L & genotype & 1,68 & 19.05 & $<0.0001$ \\
\hline & & & treatment & 3,68 & 31.65 & $<0.0001$ \\
\hline & & & genotype $x$ treatment & 3,68 & 3.56 & 0.0186 \\
\hline & & Number L & genotype & 1,68 & 35.07 & $<0.0001$ \\
\hline & & & treatment & 3,68 & 33.51 & $<0.0001$ \\
\hline & & & genotype $x$ treatment & 3,68 & 7.65 & 0.0002 \\
\hline
\end{tabular}

Only the significant ANOVA values are provided. a, repeated measures; $b$, score for the coat state at 58-day treatment; bur c, buried marbles at 20 min; L, light box. 
Table S3 Statistical analyses

\begin{tabular}{|c|c|c|c|c|c|c|}
\hline \multicolumn{7}{|c|}{ Acute \& chronic stress and fluoxetine versus basal } \\
\hline \multirow[t]{3}{*}{ Coat state } & Table 2 & Score a & genotype & 1,65 & 21.01 & $<0.0001$ \\
\hline & Table S5 & & treatment & 2,65 & 18.27 & $<0.0001$ \\
\hline & & & genotype $\mathrm{x}$ treatment & 2,65 & 5.23 & 0.0007 \\
\hline \multirow[t]{6}{*}{ Splash test } & Table 2 & Latency & genotype & 1,62 & 30.74 & $<0.0001$ \\
\hline & Table S5 & & treatment & 2,62 & 9.71 & 0.0002 \\
\hline & & & genotype $\mathrm{x}$ treatment & 2,62 & 5.44 & 0.0067 \\
\hline & & Grooming & genotype & 1,62 & 26.03 & $<0.0001$ \\
\hline & & & treatment & 2,62 & 5.06 & 0.0092 \\
\hline & & & genotype $\mathrm{x}$ treatment & 2,62 & 5.28 & 0.0076 \\
\hline \multirow{7}{*}{$\begin{array}{l}\text { Forced } \\
\text { swimming test }\end{array}$} & Table 2 & Latency & genotype & 1,74 & 50.55 & $<0.0001$ \\
\hline & Table S5 & & treatment & 3,74 & 8.60 & $<0.0001$ \\
\hline & & & genotype $\mathrm{x}$ treatment & 3,74 & 2.99 & 0.0363 \\
\hline & & Immobility & treatment & 3,74 & 25.31 & $<0.0001$ \\
\hline & & & genotype $x$ treatment & 3,74 & 9.80 & $<0.0001$ \\
\hline & & Climbing & treatment & 3,74 & 11.26 & $<0.0001$ \\
\hline & & & genotype $\mathrm{x}$ treatment & 3,74 & 9.96 & $<0.0001$ \\
\hline \multirow{2}{*}{$\begin{array}{l}\text { Tail suspension } \\
\text { test }\end{array}$} & Table 2 & Immobility & treatment & 1,42 & 11.21 & 0.0017 \\
\hline & Table S5 & & genotype $\mathrm{x}$ treatment & 1,42 & 14.93 & 0.0004 \\
\hline \multirow[t]{3}{*}{ Marble burying } & Table 2 & Number bur b & genotype & 1,65 & 33.86 & $<0.0001$ \\
\hline & Table S5 & & treatment & 2,65 & 34.77 & $<0.0001$ \\
\hline & & & genotype $x$ treatment & 2,65 & 10.33 & $<0.0001$ \\
\hline \multirow[t]{9}{*}{ Light/Dark box } & Table 2 & Latency & genotype & 1,68 & 4.42 & 0.0388 \\
\hline & Table S5 & & treatment & 3,68 & 20.65 & $<0.0001$ \\
\hline & & & genotype $\mathrm{x}$ treatment & 3,68 & 3.01 & 0.0361 \\
\hline & & Time L & genotype & 1,68 & 19.05 & $<0.0001$ \\
\hline & & & treatment & 3,68 & 31.65 & $<0.0001$ \\
\hline & & & genotype $\mathrm{x}$ treatment & 3,68 & 3.56 & 0.0186 \\
\hline & & Number L & genotype & 1,68 & 35.07 & $<0.0001$ \\
\hline & & & treatment & 3,68 & 33.51 & $<0.0001$ \\
\hline & & & genotype $\mathrm{x}$ treatment & 3,68 & 7.65 & 0.0002 \\
\hline
\end{tabular}

Only the significant ANOVA values are provided. a, score for the coat state at 58-day treatment; bur b, buried marbles at 20 min; L, light box. 
Table S3 Effects of chronic treatments on SERT densities in various areas of treated-mice

\begin{tabular}{|c|c|c|c|c|c|c|}
\hline \multirow[t]{2}{*}{ Level } & \multirow[t]{2}{*}{ Area } & \multicolumn{2}{|c|}{ WT } & \multicolumn{3}{|c|}{$\mathrm{KO}$} \\
\hline & & Epothilone & Fluoxetine & Control & Epothilone & Fluoxetine \\
\hline LC & $\begin{array}{l}\mathrm{LC} \\
\mathrm{DRI}\end{array}$ & $\begin{array}{c}+8 \% \text { ns } \\
+10 \% \text { ns }\end{array}$ & $\begin{array}{c}+4 \% \text { ns } \\
+15 \% \text { ns }\end{array}$ & $\begin{array}{c}+47 \% \text { *** } \\
+39 \% \text { * }\end{array}$ & $\begin{array}{l}+65 \% \mathrm{~ns} \\
+52 \% \mathrm{~ns}\end{array}$ & $\begin{array}{l}+63 \% \text { ns } \\
+57 \% \text { ns }\end{array}$ \\
\hline $\mathrm{Ra}$ & $\begin{array}{l}\text { RS Cx } \\
\text { DR } \\
\text { MnR } \\
\text { MEnt Cx }\end{array}$ & $\begin{array}{c}0 \% \\
+6 \% \text { ns } \\
-2 \% \text { ns } \\
-9 \% \text { ns }\end{array}$ & $\begin{array}{l}+4 \% \text { ns } \\
+6 \% \text { ns } \\
+8 \% \text { ns } \\
+1 \% \text { ns }\end{array}$ & $\begin{array}{l}-81 \% \%^{* * *} \\
+43 \% \\
+27 \% \\
-90 \%\end{array}$ & $\begin{array}{l}-85 \% \text { ns } \\
+40 \% \text { ns } \\
+39 \% \text { ns } \\
-91 \% \text { ns }\end{array}$ & $\begin{array}{l}-82 \% \text { ns } \\
+36 \% \text { ns } \\
+45 \% \text { ns } \\
-84 \% \text { ns }\end{array}$ \\
\hline SN & $\begin{array}{l}\text { RS Cx } \\
\text { Vis Cx } \\
\text { Hipp } \\
\text { SN } \\
\text { VTA } \\
\text { MEnt Cx }\end{array}$ & $\begin{array}{c}-1 \% \text { ns } \\
-4 \% \text { ns } \\
-10 \% \text { ns } \\
-5 \% \text { ns } \\
-4 \% \text { ns } \\
+5 \% \text { ns }\end{array}$ & $\begin{array}{c}+8 \% \mathrm{~ns} \\
+13 \% \mathrm{~ns} \\
+3 \% \mathrm{~ns} \\
+13 \% \mathrm{~ns} \\
+12 \% \mathrm{~ns} \\
-2 \% \mathrm{~ns}\end{array}$ & $\begin{array}{l}-81 \% \%^{* * *} \\
-84 \% \text { ***} \\
-74 \% \text { *** } \\
+35 \% \%^{* * *} \\
+45 \% \%^{* * *} \\
-80 \% \text { *** }\end{array}$ & $\begin{array}{l}-81 \% \mathrm{~ns} \\
-87 \% \mathrm{~ns} \\
-73 \% \mathrm{~ns} \\
+33 \% \mathrm{~ns} \\
+50 \% \mathrm{~ns} \\
-81 \% \mathrm{~ns}\end{array}$ & $\begin{array}{l}-84 \% \text { ns } \\
-86 \% \text { ns } \\
-72 \% \text { ns } \\
+34 \% \text { ns } \\
+36 \% \text { ns } \\
-75 \% \text { ns }\end{array}$ \\
\hline Hipp & $\begin{array}{l}\text { RS Cx } \\
\text { Mot Cx } \\
\text { Sens Cx } \\
\text { Hipp } \\
\text { BLA }\end{array}$ & $\begin{array}{c}0 \% \\
-5 \% \text { ns } \\
-6 \% \text { ns } \\
+2 \% \text { ns } \\
-13 \% \text { ns }\end{array}$ & $\begin{array}{l}+6 \% \text { ns } \\
+2 \% \text { ns } \\
+8 \% \text { ns } \\
+15 \% \text { ns } \\
+5 \% \text { ns }\end{array}$ & $\begin{array}{l}-73 \% \text { *** } \\
-78 \% \text { *** } \\
-80 \% \text { *** } \\
-41 \% \text { *** } \\
-27 \% \text { *** }\end{array}$ & $\begin{array}{l}-79 \% \text { ns } \\
-81 \% \text { ns } \\
-80 \% \text { ns } \\
-38 \% \text { ns } \\
-22 \% \text { ns }\end{array}$ & $\begin{array}{l}-73 \% \text { ns } \\
-77 \% \text { ns } \\
-78 \% \text { ns } \\
-38 \% \text { ns } \\
-22 \% \text { ns }\end{array}$ \\
\hline Str & $\begin{array}{l}\text { Cg Cx } \\
\text { Mot Cx } \\
\text { Sens Cx } \\
\text { CPu } \\
\text { Acc } \\
\text { mSept }\end{array}$ & $\begin{array}{c}+2 \% \text { ns } \\
-3 \% \text { ns } \\
-4 \% \text { ns } \\
-4 \% \text { ns } \\
0 \% \\
-3 \% \text { ns }\end{array}$ & $\begin{array}{c}+23 \% \mathrm{~ns} \\
+15 \% \mathrm{~ns} \\
+16 \% \mathrm{~ns} \\
+7 \% \mathrm{~ns} \\
+14 \% \mathrm{~ns} \\
+1 \% \mathrm{~ns}\end{array}$ & $\begin{array}{l}-76 \% \%^{* * *} \\
-61 \%^{* * *} \\
-49 \%^{* * *} \\
-50 \% \%^{* * *} \\
-33 \%^{* * *} \\
-30 \% \\
\end{array}$ & $\begin{array}{l}-75 \% \text { ns } \\
-58 \% \text { ns } \\
-43 \% \text { ns } \\
-55 \% \text { ns } \\
-45 \% \text { ns } \\
-18 \% \text { ns }\end{array}$ & $\begin{array}{l}-74 \% \text { ns } \\
-62 \% \text { ns } \\
-48 \% \text { ns } \\
-48 \% \text { ns } \\
-25 \% \text { ns } \\
-33 \% \text { ns }\end{array}$ \\
\hline
\end{tabular}

Means \pm SEM of SERT radiolabeling expressed as \% of control-treated WT respective values for 4-5 mice per genotype and per treatment. Coronal levels: LC, locus coeruleus (IA $=-1.72$ to -1.54$) ; \mathrm{Ra}$, raphe $(\mathrm{IA}=-0.80$ to -0.40$)$; $\mathrm{SN}$, substantia nigra $(\mathrm{IA}=-0.08$ to 0.88$)$; Hipp, hippocampus ( $I A=1.98$ to 2.74); Str, striatum ( $I A=4.78$ to 5.34$)$ according to Franklin \& Paxinos (1997). See abbreviations in Table S6. Three-way ANOVA followed by Student's $t$ test: ${ }^{*} p<0.050 ;{ }^{* * *} p<0.001$, comparison between genotypes; ns, not significant, comparison between treatments. 
Table S4 Effects of chronic treatments on NET densities in various areas of treated-mice

\begin{tabular}{|c|c|c|c|c|c|c|}
\hline \multirow[t]{2}{*}{ Level } & \multirow[t]{2}{*}{ Area } & \multicolumn{2}{|c|}{ WT } & \multicolumn{3}{|c|}{$\mathrm{KO}$} \\
\hline & & Epothilone & Fluoxetine & Control & Epothilone & Fluoxetine \\
\hline LC & $\begin{array}{l}\text { LC } \\
\text { DRI }\end{array}$ & $\begin{array}{c}-8 \% \text { ns } \\
-11 \% \text { ns }\end{array}$ & $\begin{array}{l}+6 \% \mathrm{~ns} \\
+1 \% \mathrm{~ns}\end{array}$ & $\begin{array}{c}-5 \% \text { ns } \\
+17 \% \text { *** }\end{array}$ & $\begin{array}{l}-2 \% \text { ns } \\
+15 \% \text { ns }\end{array}$ & $\begin{array}{c}-3 \% \text { ns } \\
+22 \% \text { ns }\end{array}$ \\
\hline $\mathrm{Ra}$ & $\begin{array}{l}\text { RS Cx } \\
\text { DR } \\
\text { MnR } \\
\text { MEnt Cx }\end{array}$ & $\begin{array}{c}+17 \% \text { ns } \\
-5 \% \text { ns } \\
-15 \% \text { ns } \\
-2 \% \text { ns }\end{array}$ & $\begin{array}{l}+21 \% \text { ns } \\
-4 \% \text { ns } \\
-2 \% \text { ns } \\
+5 \% \text { ns }\end{array}$ & $\begin{array}{l}-61 \% \text { *** } \\
+32 \text { *** } \\
+42 \% \text { *** } \\
-65 \% \text { *** }\end{array}$ & $\begin{array}{l}-64 \% \text { ns } \\
+26 \% \text { ns } \\
+51 \% \text { ns } \\
-63 \% \text { ns }\end{array}$ & $\begin{array}{l}-60 \% \text { ns } \\
+25 \% \text { ns } \\
+56 \% \text { ns } \\
-59 \% \text { ns }\end{array}$ \\
\hline SN & $\begin{array}{l}\text { RS Cx } \\
\text { Vis Cx } \\
\text { Hipp } \\
\text { SN } \\
\text { VTA } \\
\text { MEnt Cx }\end{array}$ & $\begin{array}{c}+2 \% \text { ns } \\
-7 \% \text { ns } \\
-21 \% \text { ns } \\
-18 \% \text { ns } \\
-18 \% \text { ns } \\
-6 \% \text { ns }\end{array}$ & $\begin{array}{c}+22 \% \mathrm{~ns} \\
+13 \% \mathrm{~ns} \\
+2 \% \mathrm{~ns} \\
+2 \% \mathrm{~ns} \\
+2 \% \mathrm{~ns} \\
-4 \% \mathrm{~ns}\end{array}$ & $\begin{array}{l}-60 \%{ }^{* * *} \\
-64 \% \%^{* * *} \\
-57 \% \%^{* *} \\
-2 \% \mathrm{~ns} \\
+21 \% \%^{* * *} \\
-67 \%{ }^{* * *}\end{array}$ & $\begin{array}{l}-69 \% \text { ns } \\
-68 \% \text { ns } \\
-57 \% \text { ns } \\
-16 \% \text { ns } \\
+8 \% \text { ns } \\
-66 \% \text { ns }\end{array}$ & $\begin{array}{c}-70 \% \text { ns } \\
-70 \% \text { ns } \\
-64 \% \text { ns } \\
-3 \% \text { ns } \\
+26 \% \text { ns } \\
-67 \% \text { ns }\end{array}$ \\
\hline Hipp & $\begin{array}{l}\text { RS Cx } \\
\text { Mot Cx } \\
\text { Sens Cx } \\
\text { Hipp } \\
\text { BLA }\end{array}$ & $\begin{array}{c}-2 \% \text { ns } \\
-4 \% \text { ns } \\
-5 \% \text { ns } \\
-2 \% \text { ns } \\
+16 \% \text { ns }\end{array}$ & $\begin{array}{c}0 \% \\
-8 \% \text { ns } \\
-4 \% \text { ns } \\
-3 \% \text { ns } \\
+2 \% \text { ns }\end{array}$ & $\begin{array}{l}-49 \% \text { *** } \\
-57 \% \text { *** } \\
-57 \% \text { *** } \\
-47 \% \text { *** } \\
-34 \% \text { *** }\end{array}$ & $\begin{array}{l}-51 \% \text { ns } \\
-57 \% \text { ns } \\
-54 \% \text { ns } \\
-44 \% \text { ns } \\
-32 \% \text { ns }\end{array}$ & $\begin{array}{l}-56 \% \text { ns } \\
-62 \% \text { ns } \\
-59 \% \text { ns } \\
-50 \% \text { ns } \\
-36 \% \text { ns }\end{array}$ \\
\hline Str & $\begin{array}{l}\text { Cg Cx } \\
\text { Mot Cx } \\
\text { Sens Cx } \\
\text { CPu } \\
\text { Acc } \\
\text { mSept }\end{array}$ & $\begin{array}{l}-5 \% \text { ns } \\
-1 \% \text { ns } \\
+5 \% \text { ns } \\
-4 \% \text { ns } \\
-13 \% \text { ns } \\
-10 \% \text { ns }\end{array}$ & $\begin{array}{l}-9 \% \text { ns } \\
-7 \% \text { ns } \\
+3 \% \text { ns } \\
-2 \% \text { ns } \\
-9 \% \text { ns } \\
-10 \% \text { ns }\end{array}$ & 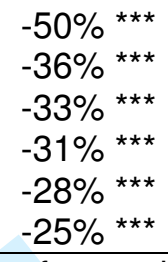 & $\begin{array}{l}-48 \% \text { ns } \\
-34 \% \text { ns } \\
-25 \% \text { ns } \\
-41 \% \text { ns } \\
-36 \% \text { ns } \\
-33 \% \text { ns }\end{array}$ & $\begin{array}{l}-53 \% \text { ns } \\
-44 \% \text { ns } \\
-42 \% \text { ns } \\
-42 \% \text { ns } \\
-37 \% \text { ns } \\
-43 \% \text { ns }\end{array}$ \\
\hline
\end{tabular}

Means \pm SEM of NET radiolabeling expressed as $\%$ of control-treated WT respective values for 4-5 mice per genotype and per treatment. Coronal levels: $L C$, locus coeruleus $(I A=-1.72$ to -1.54); $\mathrm{Ra}$, raphe $(\mathrm{IA}=-0.80$ to -0.40$)$; $\mathrm{SN}$, substantia nigra $(\mathrm{IA}=-0.08$ to 0.88$)$; Hipp, hippocampus ( $I A=1.98$ to 2.74 ); Str, striatum ( $I A=4.78$ to 5.34 ) according to Franklin \& Paxinos (1997). See abbreviations in Table S6. Three-way ANOVA followed by Student's t test: ns non significant; ${ }^{* * *} p<0.001$, comparison between genotypes; ns, not significant, comparison between treatments. 
Table S5 Performances of WT and STOP KO males after various treatments

1

2

3

4

5

6

7

8

9

10

11

12

13

14

15

16

17

18

19

20

21

22

23

24

25

26

27

28

29

30

31

32

33

34

35

36

37

38

39

40

41

42

43

44

45

46

47

48

49

50

51

52

53

54

55

56

57

58

59

60

\begin{tabular}{|c|c|c|c|c|c|c|c|c|}
\hline \multirow[t]{2}{*}{ Parameter } & \multicolumn{2}{|c|}{ Basal } & \multicolumn{2}{|c|}{ Acute stress } & \multicolumn{2}{|c|}{ Chronic stress } & \multicolumn{2}{|c|}{ Chronic fluoxetine } \\
\hline & WT & $\mathrm{KO}$ & WT & $\mathrm{KO}$ & WT & $\mathrm{KO}$ & WT & $\mathrm{KO}$ \\
\hline \multicolumn{9}{|c|}{ Coat state } \\
\hline Score 58d & $16.8 \pm 0.3$ & $10.2 \pm 0.9^{*}$ & & & $8.3 \pm 1.9 \$$ & $8.4 \pm 1.4$ & $19.6 \pm 0.2 \$ \#$ & $12.4 \pm 2.0^{*} \#$ \\
\hline \multicolumn{9}{|c|}{ Splash test } \\
\hline $\begin{array}{l}\text { Latency } \\
\text { Grooming }\end{array}$ & $\begin{array}{c}38.0 \pm 6.3 \\
137 \pm 8\end{array}$ & $\begin{array}{l}122 \pm 16^{*} \\
74 \pm 14^{*}\end{array}$ & & & $\begin{array}{c}29.4 \pm 4.5 \\
154 \pm 8\end{array}$ & $\begin{array}{c}71.7 \pm 13.3^{*} \$ \\
88 \pm 10^{*}\end{array}$ & $\begin{array}{c}27.4 \pm 4.9 \\
140 \pm 10\end{array}$ & $\begin{array}{c}45.0 \pm 3.1^{*} \$ \\
136 \pm 6 \$ \#\end{array}$ \\
\hline \multicolumn{9}{|c|}{ Forced swimming test } \\
\hline Latency & $56.0 \pm 6.1$ & $8.0 \pm 2.4^{*}$ & $65.3 \pm 7.6$ & $19.7 \pm 4.5^{\star} \$$ & $72.5 \pm 17.3$ & $21.3 \pm 8.4^{*}$ & $15.7 \pm 3.3 \$ \#$ & $5.1 \pm 1.1^{*}$ \\
\hline Immobility & $188 \pm 10$ & $241 \pm 12^{*}$ & $176 \pm 16$ & $131 \pm 22 \$$ & $126 \pm 22 \$$ & $48 \pm 10 * \$$ & $169 \pm 15$ & $238 \pm 20^{*} \#$ \\
\hline Climbing & $53.4 \pm 5.7$ & $12.8 \pm 1.8^{*}$ & $45.2 \pm 9.8$ & $55.9 \pm 10.8 \$$ & $12.9 \pm 1.8 \$$ & $30.3 \pm 6.7^{*} \$$ & $17.0 \pm 3.8 \$$ & $17.7 \pm 4.6$ \\
\hline \multicolumn{9}{|c|}{ Tail suspension test } \\
\hline Immobility & $90 \pm 7$ & $143 \pm 11^{*}$ & $96 \pm 17$ & $58 \pm 10 * \$$ & & & & \\
\hline \multicolumn{9}{|c|}{ Marble burying test } \\
\hline Number (a) & $11.4 \pm 0.3$ & $3.3 \pm 1.2^{*}$ & & & $6.4 \pm 0.8 \$$ & $3.2 \pm 0.7^{*}$ & $0.9 \pm 0.5 \$ \#$ & $0 \pm 0 \$ \#$ \\
\hline \multicolumn{9}{|c|}{ Light/dark box test } \\
\hline Latency & $66.8 \pm 10.9$ & $27.4 \pm 10.3^{*}$ & $55.9 \pm 8.1$ & $59.6 \pm 9.1 \$$ & $35.1 \pm 11.2$ & $47.4 \pm 7.6$ & $207 \pm 38 \$ \#$ & $122 \pm 26^{*} \$ \#$ \\
\hline Time L & $48.8 \pm 6.0$ & $96.1 \pm 9.1^{*}$ & $33.9 \pm 5.2$ & $46.6 \pm 7.0 \$$ & $44.4 \pm 6.4$ & $58.7 \pm 9.7 \$$ & $4.1 \pm 2.1 \$ \#$ & $13.3 \pm 4.9 \$ \#$ \\
\hline Number L & $5.6 \pm 0.7$ & $13.4 \pm 1.4^{*}$ & $4.7 \pm 0.7$ & $6.7 \pm 0.7 \$$ & $5.1 \pm 0.7$ & $7.0 \pm 0.9 \$$ & $0.9 \pm 0.4 \$ \#$ & $2.4 \pm 0.5^{\star} \$ \#$ \\
\hline
\end{tabular}

Means \pm SEM of values for 9-17 WT and STOP KO males in basal condition (Fournet et al. 2012 and this study), 9-12 WT and STOP KO males after acute stress, 9-10 WT and STOP $\mathrm{KO}$ males after chronic stress and fluoxetine treatment (mice of both genotypes in equal proportion for each test). (a) number at $20 \mathrm{~min}$; L, light box. Two-way ANOVA followed by post hoc Fisher's tests: * $p<0.05$, comparison between genotypes; $\$ p<0.05$, comparison with basal conditions; \# $p<0.05$, comparison with chronic stress. 
Table S6 Abbreviations

\begin{tabular}{|ll|ll|}
\hline Acc & nucleus accumbens & MnR & median raphe nucleus \\
BLA & baso-lateral amygdala & Mot Cx & motor cortex \\
Cg Cx & cingulate cortex & Ra & raphe \\
CPu & caudate-putamen & RS Cx & retrosplenial cortex \\
DR & dorsal raphe nucleus & Sens Cx & somatosensory cortex \\
DRI & dorsal raphe intermediate & SN & substantia nigra \\
Hipp & hippocampus & Str & striatum \\
LC & locus coeruleus & Vis Cx & visual cortex \\
mSept & medial septum & VTA & ventral tegmental area \\
MEnt Cx & medial entorhinal cortex & & \\
\hline
\end{tabular}

Abbreviations are from Franklin \& Paxinos (1997). 
A- Chronic treatments and tests

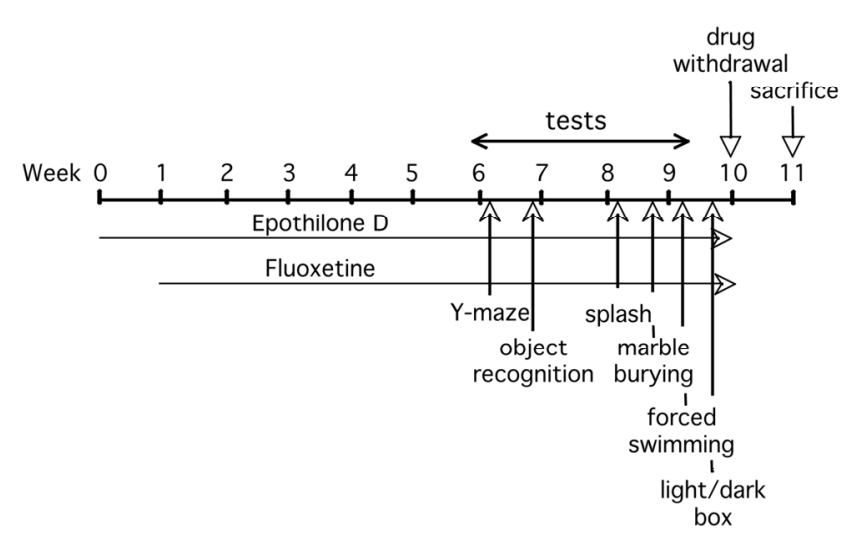

\section{B- Body weight}
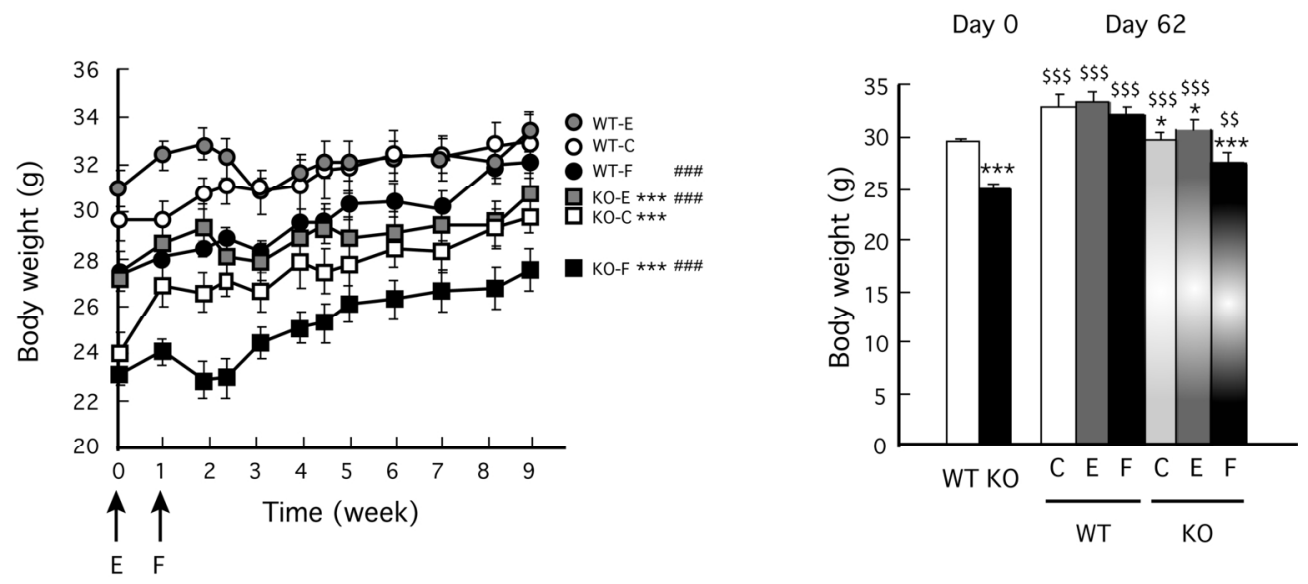

Figure S1 
A - Fluid consumption
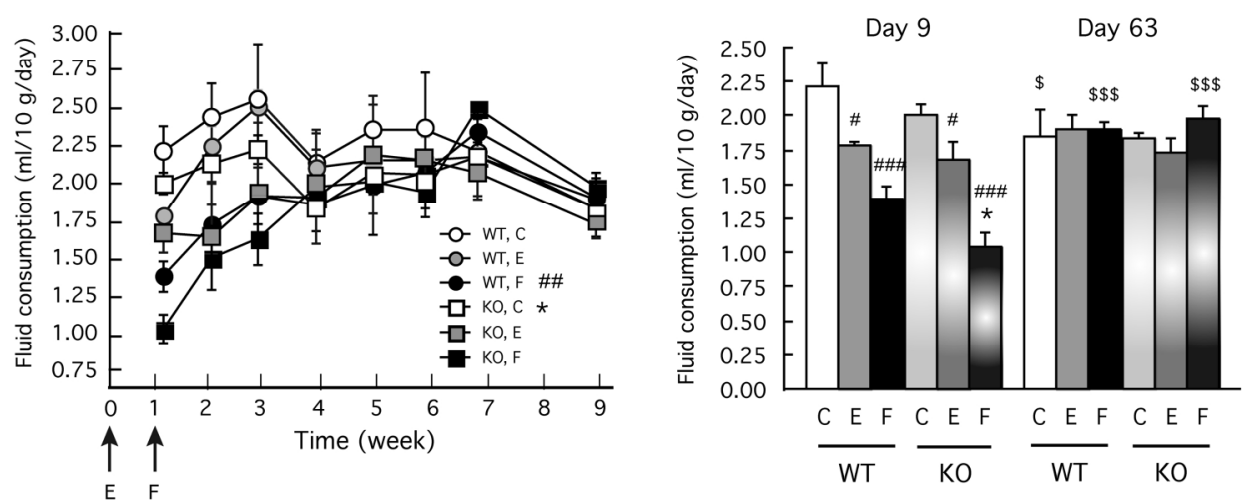

Figure S2 
Author's nam: MA.RTRES MQRie-PQScale Author's adress: Insen In UMRS 952 / CNRS UMR 7224 UPMC 9quai sTreznend caxe $37,7525.2$ Paźs Cedex.5 france

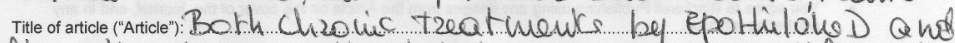
fluoxetine increas the shor-tem memory and differentially.. Manuscipt no. (f k knom)) $J N C-E-2011-0950$

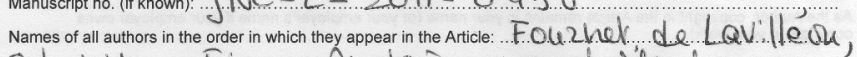
Schuleirgen, G.2n, Andzieux and fartus. In order for your Article to be distributed as widely as possible in Journal of Neurochemistry (the Journal) you grant
Blackwell Publishing Ltd (Blackwell Publishing) an exclusive licence to publish the above Article on behalf of The International Socicty for Nourochemistry including the abstract in printed and clectronic form, in all languagese, and to revisions and revivals. The Article is deemed to include all material submitted for publication with the exception of Letters, and includes the text, figures, tables, author contact details and all supplementary material accompanying the Article.

Please read this form carefully, sign at the bottom (if your employer owns copyright in your work, arrange for your employer to sign where marked), and return the ORIGINAL to the address below as quickly as possible. As author, you remain the copyright owner of the Article, unless copy
authors please note: your Article is in the public domain.) Your Article will not be published unless an Exclusive Licence Form has been signed and received by
Blackwell Publishing.

Please note: You retain the following rights to re-use the Article, as long as you do not sell or reproduce the Article or any part of it for commercial purposes (i.e. for monetary gain on your own account or on that of a third party, or for
indirect financial gain by a commercial entity). These rights apply without needing to seek permission from Blackwell Publishing.

- Prior to acceptance: We ask that as part of the publishing process you acknowledge that the Article has been submitted to the Journal. You will not prejudice acceptance if you use the unpublished Article, in form and content as submitted for publication in the Journal, in the following ways:

Sharing print or electronic copies of the Article with colleagues;
$0 \quad$ posting an electronic version of the Article on your own personal website, on your employer's

website/repository and on free public servers in your subject area.
- After acceptance: Provided that you give appropriate acknowledgement to the Journal, The Internationa Society for Neurochemistry and Blackwell Publishing, and full bibliographic reference for the Article when it is you may she print or electronic copies of the Articlew with colleaguing ways.

- you may use all or part of the Article and abstract, without revision or modification, in personal compilations or other publications of your own work;
you may use the Article within your employer's institution or company for educational or research 12 months after publication you may post an electronic version of the Article on your own personal website, on your employer's websitierepository and on free public servers in your subject area. together with the following text. 'The definitive version is available at umww blackwell-synergy Artce'

Please note that you are not permitted to post the Blackwell Publishing PDF version of the Article online. All requests by third parties to re-use the Article in whole or in part will be handled by Blackwell Publishing. Any publication (including publication by Blackwell Publishing) will be subject to your approval (which is deemed to be given if we have not heard from you within 4 weeks of your approval being sought by us writing to you at your las In signing this Agreement

1. You hereby warrant that this Article is an original work, has not been published before and is not being

2. You hereby warrant that you have obtained permission from the copyright holder to reproduce in the Article (in

3. You hereby warrant that this Article contains no violation of any existing copyright or other third party right or any

this Article does not inffinge the rights of others;
You hereby warrant that in the case of a multi-authored Article you have obtained, in writing, authorization to
enter into this Agreement on their behalf and that all co-authors have read and agreed the terms of this enter into this Agreement on their behall and that all co-authors have read and agreed the terms of this

5. You warrant that any formula or dosage given is accurate and will not if properly followed injure any person; 
6. You will indemnify and keep indemnified the Editors / The International Society for Neurochemistry and Blackwell Publishing against all claims and expenses (including legal costs and expenses) arising from any breach of this warranty and the other warranties on your behalf in this Agreement.

By signing this Agreement you agree that Blackwell Publishing may arrange for the Article to be:

- Published in the above Journal, and sold or distributed, on its own, or with other related material

- Published in multi-contributor book form or other edited compilations by Blackwell Publishing

Reproduced and/or distributed (including the abstract) throughout the world in printed, electronic or any other medium whether now known or hereafter devised, in all languages, and to authorize third parties (including

Reproduction Rights Organizations) to do the same;

- You agree to Blackwell Publishing using any images from the Article on the cover of the Journal, and in any marketing material.

You authorize Blackwell Publishing to act on your behalf to defend the copyright in the Article if anyone should infringe it, although there is no obligation on Blackwell Publishing to act in this way.

As the Author, copyright in the Article remains in your name (or your employer's name if your employer owns copyright in your work)

Blackwell Publishing undertakes that every copy of the Article published by Blackwell Publishing will include the full bibliographic reference for your Article, together with the copyright statement

\section{Z BOX A: to be completed if copyright belongs to you}

$\square$ BOX B: to be completed if copyright belongs to your employer (e.g. HMSO, CSIRO) The copyright holder grants Blackwell Publishing an exclusive licence to publish the Article including the with third parties for the full period of copyright and all renewals, extensions, revisions and revivals.

Print Name of Copyright holder:

This will be printed on the copyright line on each page of the Article. It is your responsibility to provide the correct information of the copyright holder.

$\square$ BOX C: to be completed if the Article is in the public domain (e.g. US Federal Government employees) You certify that the Article is in the public domain. No licence to publish is therefore

Signature (on behalf of all co-authors (if any))

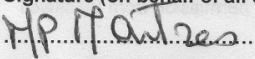
Print name: MART.RES MP

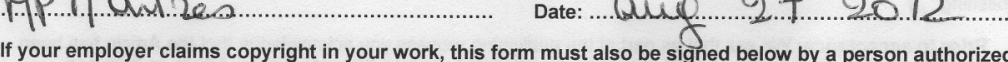
If your employer claims copyright in your work, this form must also be signed below by a person authorized to sign for and on behalf of your employer, as confirmation that your employer accepts the terms of this

Signature (on behalf of the employer of the author (s))

Print name:

Print name of employer:

Date:

The rights conveyed in this licence will only apply upon acceptance of your Article for publication.

Data Protection: The Publisher may store your name and contact details in electronic format in order to correspond with you about the publication of your Article in the Journal. We would like to contact you from time to time with

information about new Blackwell publications and services in your subject area. (For European contributors, this may involve transfer of your personal data outside the European Economic Area.) Please check the following boxcs if you are happy to be contacted in this way:

\footnotetext{
$\Phi$ (conventional mailing) $\square$ (via e-mail)
}

Please return the signed form to the editorial office that is handling your manuscript. 